\title{
Deletion of the SACPD-C Locus Alters the Symbiotic Relationship Between Bradyrhizobium japonicum USDA110 and Soybean, Resulting in Elicitation of Plant Defense Response and Nodulation Defects
}

\author{
Hari B. Krishnan, ${ }^{1,2}$ Alaa A. Alaswad, ${ }^{2,3}$ Nathan W. Oehrle, ${ }^{1}$ and Jason D. Gillman ${ }^{1,2}$ \\ ${ }^{1}$ Plant Genetics Research Unit, USDA-Agricultural Research Service, Columbia, MO 65211, U.S.A.; ${ }^{2}$ Plant Science Division, \\ University of Missouri, Columbia, MO 65211, U.S.A.; and ${ }^{3}$ King Abdul Aziz University, Jeddah, Saudi Arabia
}

Accepted 14 October 2016.

Legumes form symbiotic associations with soil-dwelling bacteria collectively called rhizobia. This association results in the formation of nodules, unique plant-derived organs, within which the rhizobia are housed. Rhizobia-encoded nitrogenase facilitates the conversion of atmospheric nitrogen into ammonia, which is utilized by the plants for its growth and development. Fatty acids have been shown to play an important role in root nodule symbiosis. In this study, we have investigated the role of stearoyl-acyl carrier protein desaturase isoform C (SACPD-C), a soybean enzyme that catalyzes the conversion of stearic acid into oleic acid, which is expressed in developing seeds and in nitrogen-fixing nodules. In-depth cytological investigation of nodule development in sacpd-c mutant lines M25 and MM106 revealed gross anatomical alteration in the sacpd-c mutants. Transmission electron microscopy observations revealed ultrastructural alterations in the sacpd-c mutants that are typically associated with plant defense response to pathogens. In nodules of two sacpd-c mutants, the combined jasmonic acid (JA) species (JA and the isoleucine conjugate of JA) were found to be reduced and 12-oxophytodienoic acid (OPDA) levels were significantly higher relative to wild-type lines. Salicylic acid levels were not significantly different between genotypes, which is divergent from previous studies of sacpd mutant studies on vegetative tissues. Soybean nodule phytohormone profiles were very divergent from those of roots, and root profiles were found to be almost identical between mutant and wild-type genotypes. The activities of antioxidant enzymes, ascorbate peroxidase, and superoxide dismutase were also found to be higher in nodules of sacpd-c mutants. PR-1 gene expression was extremely elevated in M25 and MM106, while the expression of nitrogenase was significantly reduced in these sacpd-c mutants, compared with the parent 'Bay'. Two-dimensional gel electrophoresis and matrix-assisted laser desorption-ionization time of flight mass spectrometry analyses confirmed sacpd-c mutants also accumulated higher amounts of pathogenesis-related proteins in the nodules. Our study

Corresponding author: H. B. Krishnan;

E-mail: Hari.Krishnan@ARS.USDA.GOV

*The $\boldsymbol{e}$-Xtra logo stands for "electronic extra" and indicates that five supplementary figures and two supplementary tables are published online.

This article is in the public domain and not copyrightable. It may be freely reprinted with customary crediting of the source. The American Phytopathological Society, 2016. establishes a major role for SACPD-C activity as essential for proper maintenance of soybean nodule morphology and physiology and indicates that OPDA signaling is likely to be involved in attenuation of nodule biotic defense responses.

Soybean, an economically important legume, interacts with some soil-dwelling bacteria (collectively called as rhizobia), resulting in formation of nitrogen-fixing nodules on the roots and, in a few cases, on stems. Nodules are a specialized plant organ in which atmospheric nitrogen is reduced to ammonia by the bacterial-encoded enzyme nitrogenase. This process is termed biological nitrogen fixation and contributes significantly to the overall nitrogen requirements of growing plants for the synthesis of seed storage reserves (Vance 2001).

Nodule formation is a complex and multistep process and requires the coordinated exchange of molecular signals between plants and bacteria (Perret et al. 2000). Flavonoids released from the roots interact with the rhizobium transcriptional activator protein NodD, resulting in the activation of nod genes, which leads to production of lipo-chito-oligosaccharides, termed Nod factors (Long 1996). Nod factors initiate early symbiotic events such as root-hair deformation, cortical-cell proliferation, and the entry of rhizobia into the root hairs (Relić et al. 1994). Rhizobia, which are enclosed within tubular structures called infection threads, penetrate the cortex of the root and are released into the cytoplasm of the host cells, in which they differentiate into bacteroids. The bacteroids are encased within a unique plant-derived membrane compartment, termed the symbiosome, in which the process of biological nitrogen fixation occurs (Emerich and Krishnan 2014; Roth and Stacey 1989).

Fatty acids (FA) are an important component of both the infection thread and symbiosome membranes. Both saturated (palmitic acid and stearic acid) and unsaturated fatty acids (palmitoleic acid, oleic acid, linoleic acid, and linolenic acid) occur in the symbiosome membranes of nodules (Gaude et al. 2004). Metabolomic studies have revealed the accumulation of palmitic and stearic acid in Lotus japonicus nodules (Colebatch et al. 2004; Desbrosses et al. 2005). Inoculation with Bradyrhizobium japonicum has been shown to alter the levels of fatty acids in soybean root hairs (Brechenmacher et al. 2010). The role of acyl carrier protein (GmACP), an essential cofactor protein in FA biosynthesis, in soybean root nodule symbiosis was recently investigated (Wang et al. 2014). Silencing of GmACP by RNA interference (RNAi) resulted in significant reduction in the levels of palmitic acid and stearic acid in root 
tissue and lowered the number of nodules on soybean transgenic roots (Wang et al. 2014). These studies highlight the importance of fatty acids (FA) in the establishment of root nodule symbiosis.

Stearoyl-acyl carrier protein desaturase (SACPD) enzymes play an important role in fatty acid biosynthesis. This enzyme catalyzes the conversion of stearic acid into oleic acid (Kachroo et al. 2007; Shanklin and Cahoon 1998). SACPD-encoding genes have been identified in various plant genomes (Akagi et al. 1995; Nishida et al. 1992; Shanklin and Somerville 1991; Taylor et al. 1992; Thompson et al. 1991). Multiple SACPD isozymes are present in Arabidopsis thaliana, with SSI2 being the major isoform (Kachroo et al. 2001, 2007). Interestingly, these isoforms do not have a compensatory or overlapping function, as revealed by the lack of complementation of $s s i 2$ mutant with other SACPD isoforms (Kachroo et al. 2007). The loss of SACPD activity in the Arabidopsis mutant ssi 2 results in constitutive vegetative upregulation of salicylic acid (SA)-mediated defense responses and overexpression of pathogenesis-related (PR) genes (Chandrashekara et al. 2007; Kachroo et al. 2001, 2003a and b, 2004, 2005). The two hallmark phenotypes of increased defense signaling, constitutive $P R$ gene expression and elevation of SA levels, were used in screens that identified several mutants with spontaneous vegetative lesions, including the Arabidopsis ssi2/fatb mutant (Durner et al. 1997; Ryals, et al. 1996; Shah et al. 2001). Similarly, $S A C P D$-silenced soybean plants can develop spontaneous cell-death lesions, increased SA accumulation, and constitutive expression of PR genes (Kachroo et al. 2008). Additionally, these constitutively silenced plants were also found to be somewhat resistant to bacterial and oomycete pathogens, at a substantial cost to plant size and (presumably) overall seed yield. However, it is not known if a similar plant defense response also occurs in soybean nodules initiated on the roots of sacpd-c mutant lines.

In soybean there are three $S A C P D$ gene isoforms ( $S A C P D-A$, $S A C P D-B$, and $S A C P D-C$ ) and soybean lines in which the $S A C P D-C$ locus is deleted or defective accumulate elevated seed stearic acid (Boersma et al. 2012; Gillman et al. 2014; Zhang et al. 2008). Comparative whole-genome hybridization and genetic analysis have revealed four soybean mutant lines (FN8, KK24, MM106, and M25) to be deleted for all or part of the $S A C P D-C$ locus. These mutant lines accumulated higher amounts of stearic acid in the seed, 10 to $15 \%$ compared with the 3 to $4 \%$ accumulation levels in wild-type lines (Gillman et al. 2014). The sacpd-c mutants also accumulated higher amounts of stearic acid in the nodules and exhibited altered nodule morphology and abnormalities (Gillman et al. 2014). Interestingly, the nodulation efficiency and acetylene reduction activity were not significantly different between the wild type and sacpd-c mutants, indicating that a functional SACPD-C enzyme is not critical for establishment of soybean nodulation (Gillman et al. 2014). Free-hand sections of nodules formed by sacpd-c mutants exhibited a central necrotic zone associated with discoloration. Preliminary ultrastructural investigation of the nodules formed on the roots of one of the sacpd-c mutant lines (FN8) revealed bacteroids in various stages of degradation in the cells bordering the necrotic zone, but neither the precise mechanism nor physiological consequences were reported.

In this study, we have carried out in-depth cytological investigation of nodule development, using two X-ray-induced sacpd-c mutant lines, M25 and MM106, in comparison with its parent 'Bay'. The level of plant hormones (abscisic acid [ABA], salicyclic acid [SA], and jasmonic acid [JA]) in uninoculated roots and nodules of wild-type and sacpd-c X-ray-induced mutant lines were also investigated. Additionally, we have measured antioxidant enzyme activities and have monitored changes in the protein profiles by two-dimensional gel electrophoresis and expression of selected genes by quantitative reverse transcriptionpolymerase chain reaction (qRT-PCR) during nodule development. We determined that nodules of soybean sacpd-c mutants have elevated $P R-1$ gene expression, reduced JA species accumulation (particularly the isoleucine conjugate of JA [JA-Ile]), but greatly elevated 12-oxophytodienoic acid (OPDA) levels as compared with wild-type nodules. Our observations differ from previous studies conducted on vegetative tissue that found downregulation of $S A C P D /$ ssi2/fatb gene expression results in increased SA levels and unaltered JA levels. The results of our study demonstrate a critical role for SACPD-C enzymes in nodule maintenance and control of symbiosis and plant defense response and indicate a potential role for OPDA in nodule defense signaling networks.

\section{RESULTS}

\section{sacpd-c mutants are not compromised in nodule formation.}

Previously, it was reported that Bradyrhizobium japonicuminduced nodules on the roots of sacpd-c mutant lines A6, FN8, 194D, KK24, and FAM94-41 exhibited gross morphological defects (Gillman et al. 2014). To examine if a similar response also occurs in other sacpd-c mutants, we examined the nodules formed on two of the X-ray-induced mutant lines, M25 and MM106, and the parent cultivar Bay. MM106 contains a large deletion (approximately $2.5 \mathrm{Mbp}$ ) that includes the $S A C P D-C$ locus, while M25 has a single base deletion in the coding region of the $S A C P D-C$ gene, resulting in a frameshift mutation (Supplementary Fig. S1).

RNAi-mediated silencing of a soybean acyl carrier protein (GmACP) gene has been reported to result in approximately $45 \%$ reduction in nodule numbers when compared with control plants (Wang et al. 2014). To examine if a similar reduction in nodule number also occurs as a consequence of sacpd-c mutation, we inoculated soybean roots of lines sacpd-c mutant M25 and MM106 and the parent 'Bay' with Bradyrhizobium japonicum USDA110. The total number of nodules formed on the roots was counted at 15 and 30 days after inoculation (dai). The number of nodules at both 15 and 30 dai were not significantly different between the wild-type and sacpd-c mutant lines (Table 1). Even though the nodule and shoot fresh weights were comparable at 15 dai, a significant difference was observed at 30 dai. The nodule fresh weight of sacpd-c mutant lines was

Table 1. Shoot and nodule biomass and nodule number among genotypes after inoculation by Bradyrhizobium japonicum USDA110

\begin{tabular}{|c|c|c|c|c|c|}
\hline Measurement & dai & 'Bay' & M25 & MM106 & ANOVA ( $P$ value) \\
\hline \multirow[t]{2}{*}{ Shoot fresh weight (g) } & 15 & $1.6 \pm 0.2 \mathrm{a}$ & $1.4 \pm 0.1 \mathrm{a}$ & $1.1 \pm 0.3 \mathrm{~b}$ & $0.0033 * *$ \\
\hline & 30 & $3.2 \pm 0.6 \mathrm{a}$ & $2.2 \pm 0.3 b$ & $2.3 \pm 0.3 b$ & $0.002 * *$ \\
\hline \multirow[t]{2}{*}{ Nodule number } & 15 & $41.2 \pm 12.7 \mathrm{a}$ & $38.7 \pm 10.9 \mathrm{a}$ & $47.5 \pm 9.4 \mathrm{a}$ & $0.3859 \mathrm{NS}$ \\
\hline & 30 & $37.2 \pm 6.3 \mathrm{a}$ & $38.5 \pm 7.3 \mathrm{a}$ & $46.3 \pm 17.3 \mathrm{a}$ & $0.3519 \mathrm{NS}$ \\
\hline \multirow[t]{2}{*}{ Nodule fresh weight (mg) } & 15 & $135.4 \pm 26.9 \mathrm{a}$ & $148.2 \pm 39.9 \mathrm{a}$ & $179 \pm 78.5 \mathrm{a}$ & $0.3689 \mathrm{NS}$ \\
\hline & 30 & $157.8 \pm 31.9 \mathrm{a}$ & $195 \pm 39.7 b$ & $298.5 \pm 86.2 b$ & $0.0021 * *$ \\
\hline
\end{tabular}

${ }^{\mathrm{z}}$ dai = days after inoculation; ANOVA = analysis of variance. Values followed by the same letter are not significantly different. Asterisks indicate ANOVA significance at the $<0.05(*)$ or $<0.01(* *)$ level. NS indicates insignificant differences between means. 
greater (M25 was $123 \%$ and MM106 was $189 \%$ ) than that of the parent 'Bay' at 30 dai. In contrast, the shoot fresh weight of sacpd-c mutant lines M25 and MM106 was 31 and 28\%, respectively, lower than that of the parent 'Bay' at 30 dai (Table 1).

We also examined the response of sacpd-c mutant lines to soybean cyst nematode ( $\mathrm{SCN}$ ) inoculation. 'Bay', M25, and MM106 were evaluated for potential resistance to SCN (race 3/HG type7). All three lines evaluated were not significantly different from susceptible check lines (Supplementary Table S1). Although sacpd-c mutant lines have altered fatty acid composition than that of 'Bay', no differences were detected in response to susceptibility to SCN.

\section{sacpd-c mutants reveal prominent necrotic regions} in the infected regions of the nodule.

Visual observation of free-hand sections of 30-day-old 'Bay' nodules revealed rhizobia infected zones that were pinkish in color (Fig. 1A). In contrast, nodules formed on the roots of sacpd-c X-ray-induced mutant lines M25 and MM106 revealed infected zones that were mostly brownish in color, though some areas with pinkish color were also observed (Fig. 1B and C).
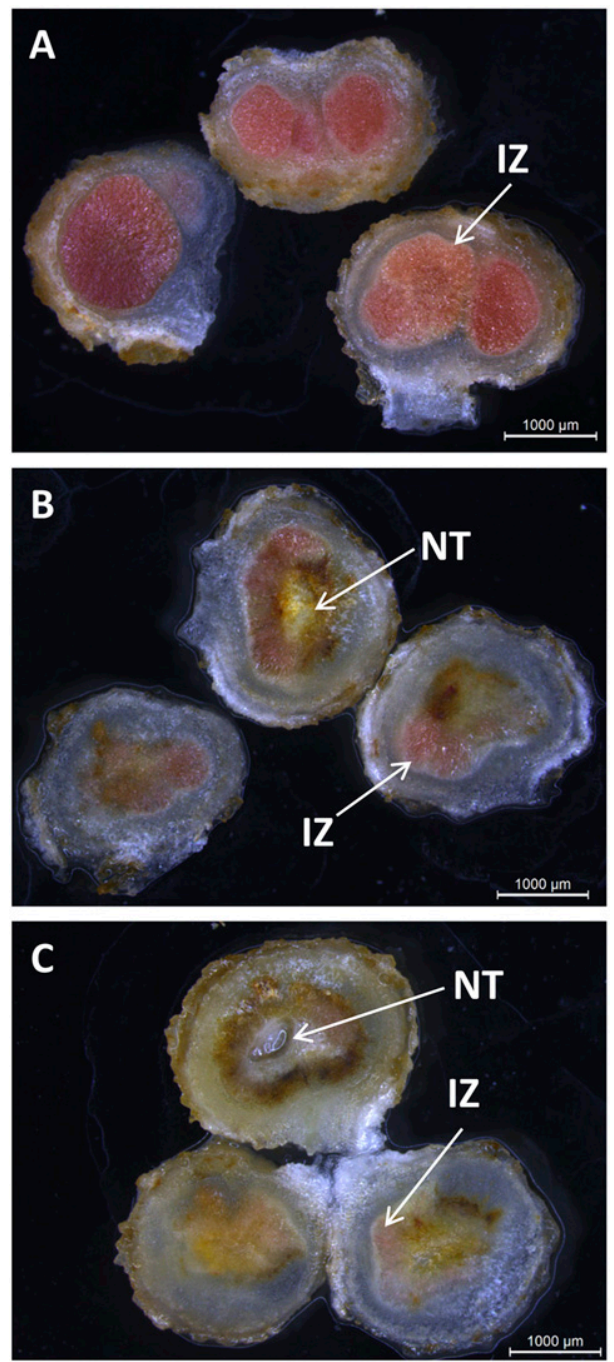

Fig. 1. Internal appearance of soybean nodules. A, Free-hand sections of 30-day-old nodules induced by Bradyrhizobium japonicum USDA110 on the roots of parent cultivar Bay and sacpd-c mutant lines B, M25 and C, MM106 were viewed by bright field microscopy. Note the presence of infection zone (IZ) and necrotic tissue (NT) in B and C and the liquid-filled cavity (C) in the nodules of sacpd-c mutant lines.
The discolored regions were much more pronounced in MM106 and often showed necrotic tissue and fluid-filled cavities (Fig. 1B and C). In addition to Bradyrhizobium japonicum, other rhizobia, including B. elkani, B. liaoningense, B. yuanmingense, and some species of Sinorhizobium fredii, can form nitrogen-fixing nodules on soybean roots. To examine if the gross morphological defects observed in the nodules initiated by $B$. japonicum are also present in nodules formed by other rhizobia, we inoculated sacpd-c mutant lines with some of these rhizobia and evaluated the nodule structure of 30-day-old nodules. Irrespective of the rhizobial strain used as inoculum, nodules formed on sacpd-c mutant lines showed central necrotic zones with brownish coloration (Supplementary Fig. S2).

\section{Anatomy of nodules of sacpd-c mutant lines shows} signs of plant defense response.

Light microscopic examination of 30-day-old 'Bay' nodules stained with hematoxylin and eosin revealed a layer of epidermis followed by a sclerenchymatous cell layer (Fig. 2A). Below this layer was the nodule cortex that was made up of parenchyma cells. Well-defined vascular bundles were visible in this region. Both infected and uninfected cells occupied the central portion of the nodule. The infected cells contained a prominent nucleus (Fig. 2A). Similar anatomical features were observed in both M25 and MM106 nodules with regard to epidermis, sclereid cell layer, and the cortex (Fig. 2B to D). However, the central infected zone (Fig. 2A to D) was clearly distinctly different from that of the 'Bay' nodule; a clearly defined central infected zone with prominent nuclei was not seen in M25 and MM106 nodules. Instead, prominent sections of the infected zone with pronounced blue- and pink-colored regions were visible (Fig. 2B to D). Hematoxylin stains nucleic acids a deep blue color, while eosin stains proteins nonspecifically a pink color. M25 and MM106 nodules contained prominent dark blue-colored regions that were surrounded by pink staining areas (Fig. 2B to D). The structural features of the 'Bay' nodule typify
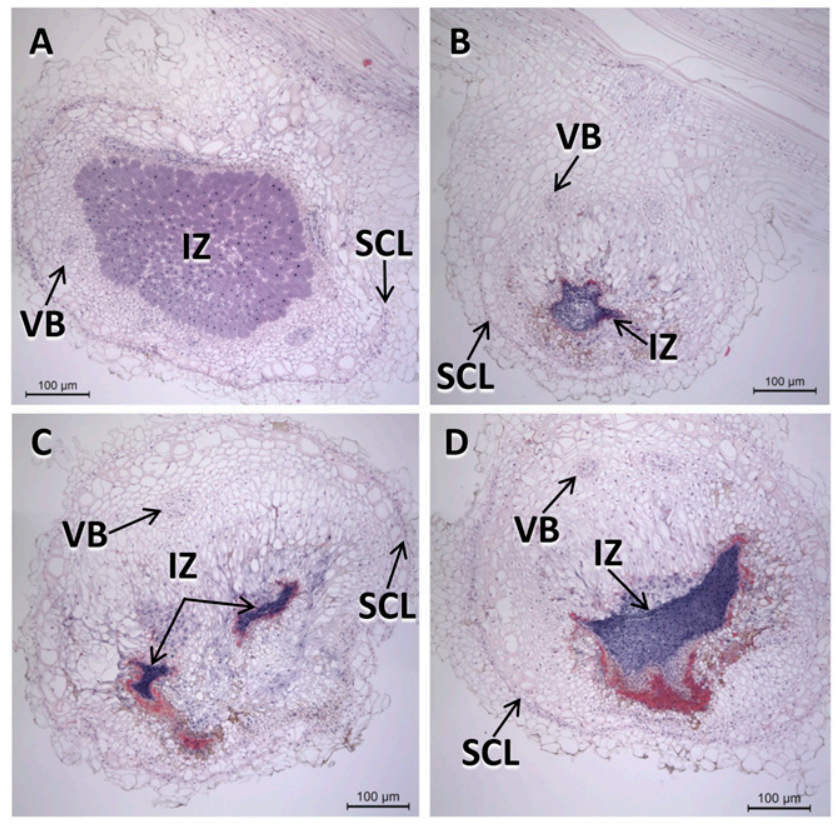

Fig. 2. Light micrographic study of soybean nodules. Nodules collected at 30 days after inoculation were embedded in paraffin. Sections were stained with hematoxylin and eosin. A, Nodules of 'Bay'induced by Bradyrhizobium japonicum USDA110 contain a central infection zone (IZ) that is filled with bacteria, while in B, M25 nodules and C, and D, MM106 nodules, the distribution of the bacteria is restricted and is demarcated by intense stain. $\mathrm{VB}=$ vascular bundle and SCL $=$ sclereid cell layer. 
normal symbiotic response, while those of M25 and MM106 appear to be associated with plant defense response against pathogen infection.

\section{sacpd-c mutants M25 and MM106 reveal dramatic ultrastructural changes during nodule growth and maturation.}

To investigate the temporal changes in the ultrastructure of nodules that eventually results in necrotic zones in mature nodules, we explored the anatomy of soybean nodules at 7 , 15 , and 30 dai by transmission electron microscopy. Electron micrographs of thin sections of 7-dai 'Bay' nodules revealed actively dividing cortical cells that contained numerous vacuoles, prominent nuclei, and numerous mitochondria (Fig. 3A). These cells also contained abundant tubular endoplasmic reticulum (ER). Infection threads that had penetrated the cortical cells were also seen (Fig. 3A). In most cases, individual rhizobia that were released from the infection threads were encapsulated in membranous structures. In some cases, rhizobia undergoing division were also seen in these structures (Fig. 3B). At 15 dai, the infected cells of 'Bay' nodules were completely occupied by rhizobia that have differentiated into bacteroids and were surrounded by peribacteroid membranes (symbiosomes) (Fig. 3C). Prominent peroxisomes were observed in uninfected cells (Fig. 3C). Symbiosomes in 30-day-old nodules were enlarged and often contained more than one bacteroid (Fig. 3D). Poly- $\beta$-hydroxybutyrate (PHB) crystals were seen in the bacteroids (Fig. 3D). The bacteroids exhibited heterogeneous size; some were long, while others were small and spherical (Fig. 3D).

Transmission electron microscopic examination of 7-dai nodules of sacpd-c mutant M25 revealed cortical cells that contained dense cytoplasm with a prominent nucleus (Fig. 4A). Numerous vacuoles, some with membranous inclusions, were found in the cortical cells. Infection thread appressed between cell walls was also observed (Fig. 4A). Unlike in 'Bay' nodules, the cortical cells were not compactly arranged, were disorganized, and contained intercellular spaces (Fig. 4A and B). Bacteria enclosed in membranes, presumably released from infection threads, were seen in some of the cells (Fig. 4A and B). Interestingly, a large number of free-living rhizobia bacteria were also found to occupy the intercellular spaces (Fig. 4B). Infected cells also contained prominent mitochondria and ER. The ER was dilated and occurred both in bacterial uninfected and infected cells (Fig. 4C and D). Dark osmophilic deposit was also observed near the intercellular spaces (Fig. 4D).
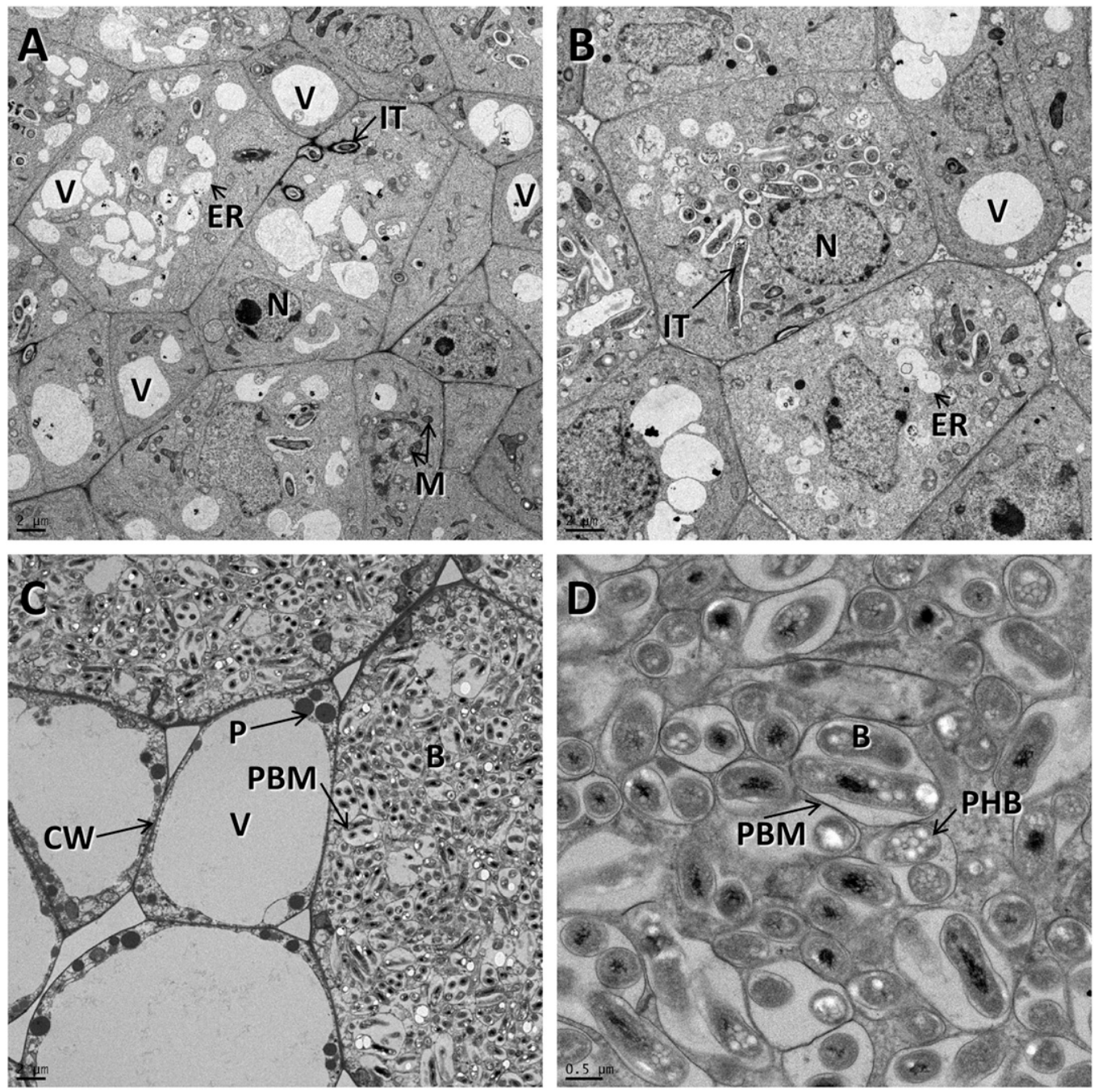

Fig. 3. Transmission electron micrographs of soybean genotype 'Bay' nodules. A and $\mathbf{B}$, Thin sections of soybean nodules, at 7, C, 15, and $\mathbf{D}, 30$ days after inoculation (dai), were examined via electron microscopy. Note the presence of infection thread (IT) (in A) and prominent nuclei (N) in 7-dai nodules. The uninfected cells contain large central vacuoles $(\mathrm{V})$ and prominent peroxisomes $(\mathrm{P})$ (in C). Infected cells in 30-dai nodules are packed with symbiosomes enclosing bacteroids (B) (in D). $\mathrm{CW}=$ cell-wall, $\mathrm{ER}=$ endoplasmic reticulum, $\mathrm{PHB}=$ poly- $\beta$-hydroxybutyrate, and $\mathrm{PBM}=$ peribacteroid membrane. 
The ultrastructural abnormalities observed in 7-dai nodules of M25 sacpd-c mutant were further intensified during nodule development. An examination of 15-dai nodules revealed the breakdown of cellular integrity (Fig. 5A and B). Infected cells contained prominent dark-staining osmophilic cell walls (Fig. 5B). At this developmental stage, the bacteroids in the infected cells appear to be at various stages of disintegration (Fig. 5B). Another striking aspect is the appearance of numerous vacuoles in the infected cells, presumably formed by fusion of several degenerating symbiosomes (Fig. 5B). Prominent mitochondria and oil bodies were also observed in these cells (Fig. 5B). At 30 dai, nodule cells revealed the complete breakdown of internal organization (Fig. 5C). The symbiosomes have disintegrated, resulting in the release of bacteria into the host cytoplasm (Fig. $5 \mathrm{C}$ ), which is marked by the presence of abundant oil bodies (Fig. 5C). These oil bodies were large, were uniform in appearance, and were mostly round in shape (Fig. 5C). Additionally, the plant cell walls have undergone extensive secondary thickening (Fig. 5D), a trait associated with plant defense response.

An examination of 7-dai MM106 nodule sections by electron microscopy revealed compactly arranged cortical cells with granular cytoplasm. Vacuoles were prominent and the contents of most of these vacuoles had membranous inclusions (Fig. 6A). Mitochondria and Golgi apparatus and ER were commonly found near the periphery of the cells. Infection threads in close contact with the cell wall were seen penetrating the interior of the cells (Fig. 6A and B). The cells also contained a few encapsulated bacteria that were presumably released from the infection threads. Interestingly, a dramatically different picture emerged from cells that were separated by only a few cell layers. Dark-staining osmophilic substances were prominently seen in nodule cells (Fig. 6C and D). Observable changes included widespread disruption of the host cytoplasm, loss of cell organelle integrity, and the appearance of large vacuolar structures (Fig. 6C and D). Such drastic ultrastructural changes were not observed in 7-dai 'Bay' and M25 nodules (Fig. 3A and B).

Electron microscopy observation of 15-dai MM106 nodules revealed some infected cells displayed the normal ultrastructure (Fig. 7A). These cells contained densely packed bacteroids enclosed within peribacteroidal membranes. Often the symbiosomes contained more than one bacteroid inside them, with prominent PHB granules (Fig. 7A). However, an examination of maturing MM106 nodules revealed a large proportion of nodule cells exhibit drastic
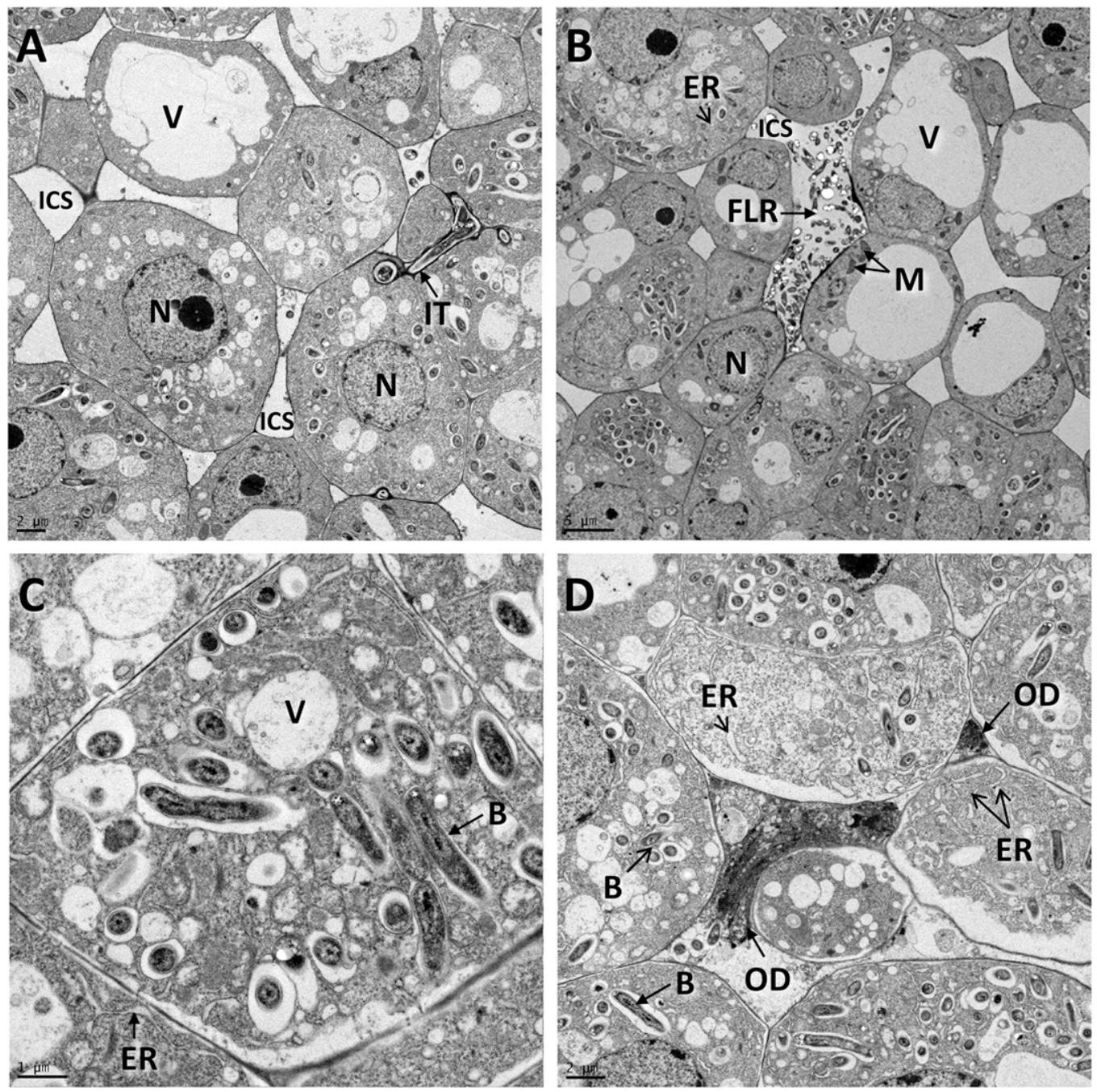

Fig. 4. Transmission electron micrographs of nodules of sacpd-c mutant line M25 7 days after inoculation (dai). Prominent vacuoles (V) and nucleus (N) are observed in the infected region of 7-dai nodules. A, Infection thread (IT) adjacent to the cell-wall and $\mathbf{B}$, free-living rhizobia in the intercellular spaces are also seen. $\mathbf{C}$ and $\mathbf{D}$, Tubular rough endoplasmic reticulum (ER) is also prominent in these cells. $\mathrm{B}=$ bacteroids, OD $=$ osmophilic deposit, ICS $=$ intercellular space, and FLR = free living bacteria. 
structural alteration (Fig. 7B to D). Such cells contained large vacuoles inside which a network of membranes was found (Fig. 7B). Electron micrographs of 30-dai nodules revealed the presence of large numbers of free-living bacteria in some cells (Fig. 7C). These bacteria, which were not enclosed by peribacteroidal membrane, contained dark electron-dense material. Some of the bacteria also contained abundant PHB granules (Fig. 7C). In a few cases, compactly packed bacteria were seen lining a central vacuole (Fig. 7D). Mitochondria and peroxisomes were also observed surrounding the central vacuole that was enclosed by a thick layer of darkstaining material (Fig. 7C).

We also examined the anatomy of the uninoculated roots by both light and electron microscopy. Light microscopic observation of uninoculated 17-day-old roots of 'Bay', M25, and M106 revealed anatomical features typical of a dicot root (Supplementary Fig. S3). A multilayer cortex region that was composed of parenchymatous cells followed the outer-most epidermal layer. The vascular bundle was demarked from the cortex by endodermis. Electron microscopy observation of the cortical cells revealed a prominent central vacuole. Cell walls with middle lamella were prominent. Few organelles were present in these cells. In a small number of cells, mitochondria and the nucleus were seen to be appressed close to cell walls.
Overall, the anatomy of the root cells of 'Bay', M25, and M106 were very similar. These observations indicate that the drastic ultrastructural changes observed in the nodules of M25 an M106 are specific to nodules and are not due to a pleiotropic effect of the sacpd-c mutation on root morphology.

\section{qRT-PCR analysis}

\section{of nitrogenase and $P R-1$ gene expression.}

We utilized qRT-PCR to probe gene expression at two stages of nodule development (15 and 30 dai) in sacpd-c mutant lines. For clarity, gene expression was expressed relative to the same nodule developmental stage for the wild-type 'Bay' line. Bradyrhizobium-encoded nitrogenase, which is critical for nitrogen fixation, was expressed at consistently lower rates in both mutant lines at both the early stage (2.1-fold lower in M25 and 2.8-fold lower in MM106) and at the later stage (4.8-fold lower in M25 and 2.6-fold lower in MM106 [Fig. 8]). Conversely, soybean-encoded $P R-1$ gene expression was extremely elevated in M25 and MM106 at the early stage (13.5- and 8.3-fold higher than 'Bay') and at the later developmental stage (8.7- and 11-fold higher than in 'Bay' [Fig. 8]). We observed large variability between biological replicates for $P R-1$ gene expression in both sacpd-c mutant lines, which may be due to differences in nodule developmental stages.
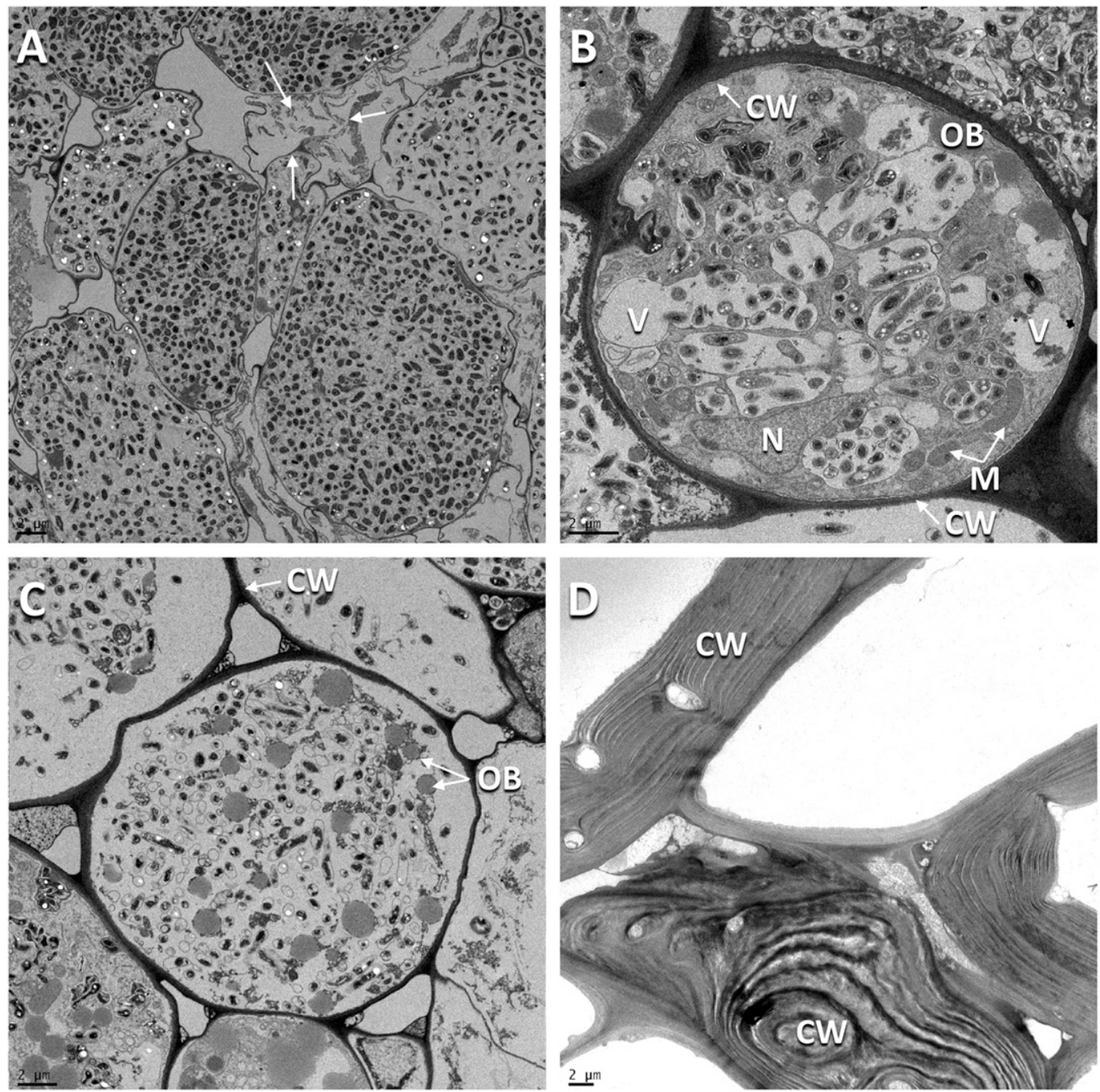

Fig. 5. Ultrastructural alterations in older nodules of sacpd-c mutant line M25. Nodules at both $\mathbf{A}$ and $\mathbf{B}, 15$ days after inoculation (dai) and $\mathbf{C}$ and $\mathbf{D}, 30$ dai reveal the loss of internal organization (A, B, and C) and disintegration of symbiosome (B and C). Note the collapse of cellular structure, indicated by arrows (A). Cell walls $(\mathrm{CW})$ feature prominent with osmophilic inclusions in the intercellular spaces (B and C). Note the presence of numerous oil bodies (OB) (in C) and secondary thickening of the plant cell-walls (CW) (in $\mathrm{D}$ ). $\mathrm{M}=$ mitochondria, $\mathrm{N}=$ nucleus, and $\mathrm{V}=$ vacuole. 
As a control, we also examined the expression of $P R-1$ and nifD in uninoculated roots in 15- and 30-day-old roots by qRT-PCR. $P R-1$ expression in M25 15-day-old roots was significantly higher than wild type. $P R-1$ gene expression was also slightly higher in 15-day-old roots of MM106 compared with wild-type roots, but differences were not significant (Fig. 8; Supplementary Table S2). In 30-day-old roots, no significant differences in the expression of $P R-1$ were detected between any of the genotypes. NifD gene expression was not detectable in uninoculated roots at either developmental stage (Fig. 8).

Analysis of protein changes in nodules of sacpd-c mutants.

To investigate if mutations affecting the $S A C P D-C$ gene result in any protein changes in nodules, we isolated nodule cytosol and bacteroid protein fractions and subjected them to sodium dodecyl sulfate-polyacrylamide gel electrophoresis (SDS-PAGE) (Supplementary Fig. S4). Estimation of nodule cytosol protein content by Quick Start Bradford protein assay indicated that 'Bay' nodules had approximately two to three times more protein than the sacpd-c mutants M25 and MM106. An examination of Coomassie Blue R-250-stained SDS-PAGE gels clearly establishes this difference in the protein content. Even though there was a significant difference in the protein content, the overall nodule protein profiles were very similar between 'Bay' and the sacpd-c mutants. We also conducted whole proteome analysis of nodule cytosol by utilizing two-dimensional electrophoresis; two-dimensional gel analysis of nodule cytosol resulted in the separation of several hundred-protein spots (Fig. 9). Even though the number of various protein spots seen in 'Bay' and M25 nodule cytosol at 15 and 30 dai were similar, differences in the intensity of several protein spots were noticeable (Fig. 9). Leghemoglobin in soybean resolved into four abundant spots (Lba, Lbc1, Lbc2, and Lbc3). The concentration of all these four spots was lower in M25 nodules when compared with 'Bay' nodules, both at 15 and 30 dai (Fig. 9). Using Delta2D v3.6 image analysis software, we quantified the signal of these protein spots. This analysis indicated that the signal intensity of protein spots Lba, Lbc1, Lbc2, and Lbc3 from M25 nodules were reduced $37,20,56$, and $50 \%$, respectively, when compared with 'Bay' nodules. The intensity of the protein spot corresponding to lipoxygenase (Oehrle et al. 2008) increased in 30-dai nodules when compared with 15-dai nodules. This increase was seen in both 'Bay' and M25 nodules (Fig. 9). Similarly, two-dimensional gel analysis of nodule cytosol proteins isolated from 'Bay' and MM106 revealed essentially the same pattern as observed between 'Bay' and M25 (Supplementary Fig. S5).
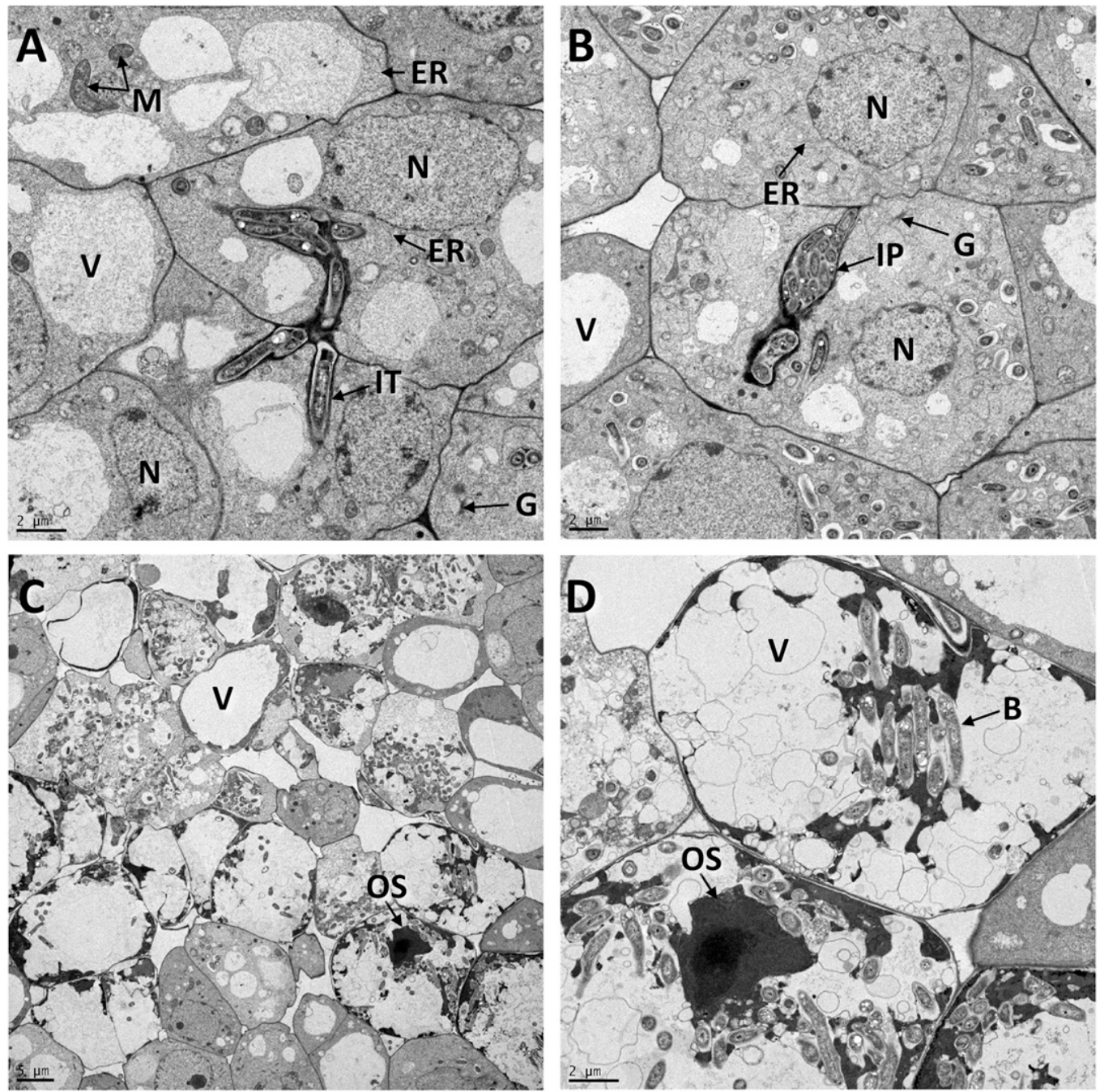

Fig. 6. Transmission electron micrographs of nodules of sacpd-c mutant line MM106 7 days after inoculation. A, Infection threads (IT) and B, infection pockets (IP) can be seen in infected cells. Cells contain prominent nuclei (N) (in A and B) and extensive endoplasmic reticulum (ER) (in B). In contrast, some cells also show significant loss of internal organization and accumulation of osmophilic substances $(\mathrm{OS})$ and numerous vacuoles $(\mathrm{V})$ ) within these cells (in $\mathrm{C}$ and $\mathrm{D})$. B $=$ bacteroids and $\mathrm{G}=$ Golgi apparatus. 
Two-dimensional gel comparison of nodule cytosol proteins also revealed a cluster of five protein spots migrating around $17 \mathrm{kDa}$ with an acidic isoelectric point that was expressed at higher levels in M25 nodules than in 'Bay' nodules (Fig. 9). We excised these protein spots from the gel, digested them with trypsin, and analyzed them by matrix-assisted laser desorption-ionization time of flight mass spectrometry (Table 2). Based on this analysis, the tryptic peptides of these four protein spots were shown to have significant sequence homology to soybean pathogenesis protein 10-like proteins and disease resistance response protein DRRG49-C from Glycine soja (Table 2).

\section{Nodule reactive oxygen species (ROS)-related enzyme activity.}

Antioxidant enzymes are abundant in legume nodules and are crucial for scavenging the ROS and reactive nitrogen species, thus protecting cells from oxidative damage (Matamoros et al. 2003). We measured the activities of three key antioxidant enzymes, ascorbate peroxidase (APX), catalase (CAT), and superoxide dismutase (SOD), from 15- and 30-dai nodules. APX catalyzes the reduction of $\mathrm{H}_{2} \mathrm{O}_{2}$ to water by ascorbate. This enzyme, in addition to its protective role against oxidative stress, also is implicated in defense against pathogens (Oliveira et al. 2014). The APX activity in 15-dai nodules of sacpd-c mutant lines M25 and MM106 was higher than the parent 'Bay' (Table 3). This difference was much more pronounced in nodules harvested at 30 dai. The sacpd-c mutant lines M25 and MM106 had about three-fold higher levels of APX activity when compared with parent 'Bay'. In contrast, the activity level of CAT, which breaks down $\mathrm{H}_{2} \mathrm{O}_{2}$ to $\mathrm{H}_{2} \mathrm{O}$ and molecular oxygen, was higher in 'Bay' nodules at both 15 and 30 dai in comparison with those of M25 and MM106. The CAT activity level in 30dai nodule extracts was about two- to threefold lower in sacpd-c mutant lines (Table 3 ). The activity of SOD, which catalyzes the dismutation of superoxide radicals into molecular oxygen and water, in 15-dai nodules was comparable among three soybean genotypes. However, at 30 dai, the SOD activity level was significantly higher in sacpd-c mutant lines M25 and MM106 (Table 3). We also measured the concentration of malondialdehyde (MDA), one of the final products of lipid peroxidation and an indicator of oxidative stress, in the nodules of the three soybean genotypes. Even though the levels of MDA were slightly higher in 15-dai nodules compared with 30-dai nodules, these differences were not significant among the three soybean genotypes (Table 3).
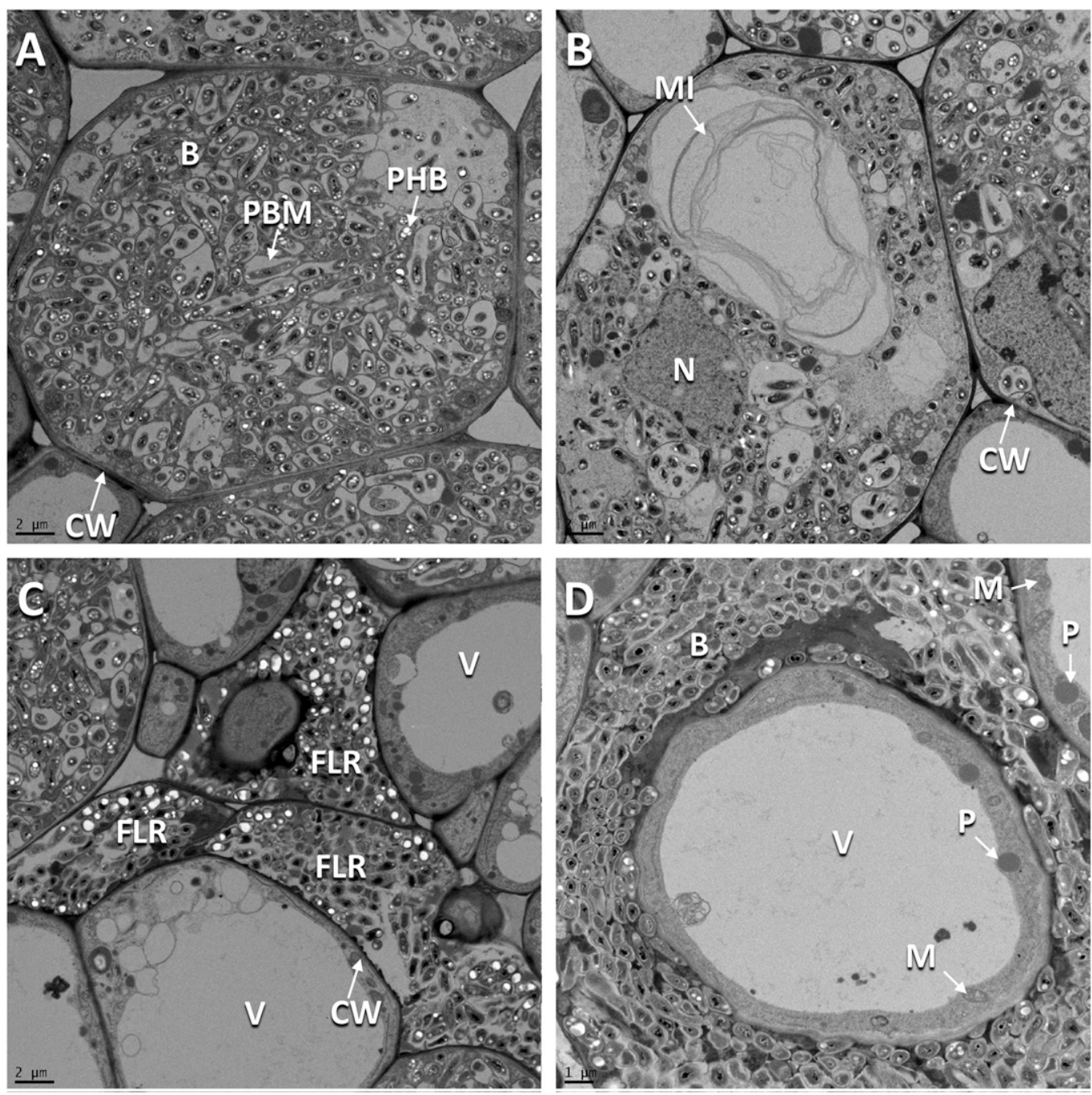

Fig. 7. Ultrastructural alterations in older nodules of sacpd-c mutant line MM106. A and B, At 15 days after inoculation (dai), vacuoles containing disintegrating rhizobia (A) and membranous inclusions (MI) (in B) can be seen. Note the symbiosome are dilated into sac-like structures. C and D, At 30 dai nodules, the bacteroids (B) are no longer enclosed within the peribacteroid membranes and are compactly packed and appear to be free-living. Note the presence of a central cavity surrounded by thickened cell-wall (CW) (in D). $\mathrm{N}=$ nucleus, $\mathrm{PBM}=$ peribacteroid membrane, $\mathrm{PHB}=$ poly- $\beta$-hydroxybutyrate, $\mathrm{V}=$ vacuole, and FLR = free-living rhizobia. 


\section{Measurement of ABA, SA, JA, and OPDA.}

Our anatomical and biochemical analysis have shown that the interaction of $B$. japonicum USDA110 with the roots of sacpd-c mutant lines M25 and MM106 results in the formation of aberrant nodules displaying strong defense responses. Plant hormones JA, SA, and ABA play a role in plant defense responses (Kunkel and Brooks 2002; Pieterse et al. 2009). Therefore, we examined the levels of SA, ABA, the jasmonate family of growth regulators, and OPDA in 30-dai nodules by liquid chromatography-tandem mass spectrometry (LC-MS/MS). The concentrations of ABA in M25 and MM106 nodules were slightly higher than in 'Bay' nodules, but this difference was not statistically significant (Table 4). Interestingly, the concentration of SA, a key player in plant defense, was similar in all three soybean genotypes. The jasmonate family of growth regulator comprises JA-Ile (Bosch et al. 2014). The biosynthetic precursor OPDA has recently been identified to have defense and physiological activities independent of COI1/JA signaling (Wasternack and Strnad 2016). The concentration of JA was significantly lower in M25 nodules compared with 'Bay' and MM106 nodules (Table 4). M25 and MM106 exhibited a sevenfold and twofold reduction, respectively in JA-Ile levels in comparison with the parental 'Bay'. OPDA was strikingly higher in the nodules of sacpd-c mutant lines M25 and MM106; OPDA was about 3.5-fold higher in the nodules of sacpd-c mutant lines when compared with 'Bay' nodules (Table 4). For comparison, we also quantified hormone levels from uninoculated roots. Our analysis revealed that the hormone levels in roots were not substantially different between genotypes, except for JA-Ile, which was very slightly lower in both SAPCD mutants $(82.4 \%$ for M25 and $67.9 \%$ for MM106, relative to 'Bay') (Table 4). SA, ABA, JA, and OPDA levels were not different between uninoculated roots of wild type and mutant lines.

\section{DISCUSSION}

\section{Ultrastructural consequences}

of deletion of the $S A C P D-C$ gene.

During the initial phases of nodulation, rhizobia are often recognized as pathogens and the roots respond with a weak and transitory plant defense response (Mithöfer 2002). The rhizobiainduced defense response has also been suggested to play an important role in regulating the nodule number (Vasse et al. 1993). In our study, the number of nodules formed on the roots of the sacpd-c mutant lines and the parent 'Bay' are not significantly different. This observation precludes any role for the $S A C P D-C$ locus in regulating nodule number. A comparative ultrastructural examination of nodules of sacpd-c mutant lines and the parent 'Bay' reveals a drastic difference in their response to inoculation with Bradyrhizobium japonicum USDA110 (and
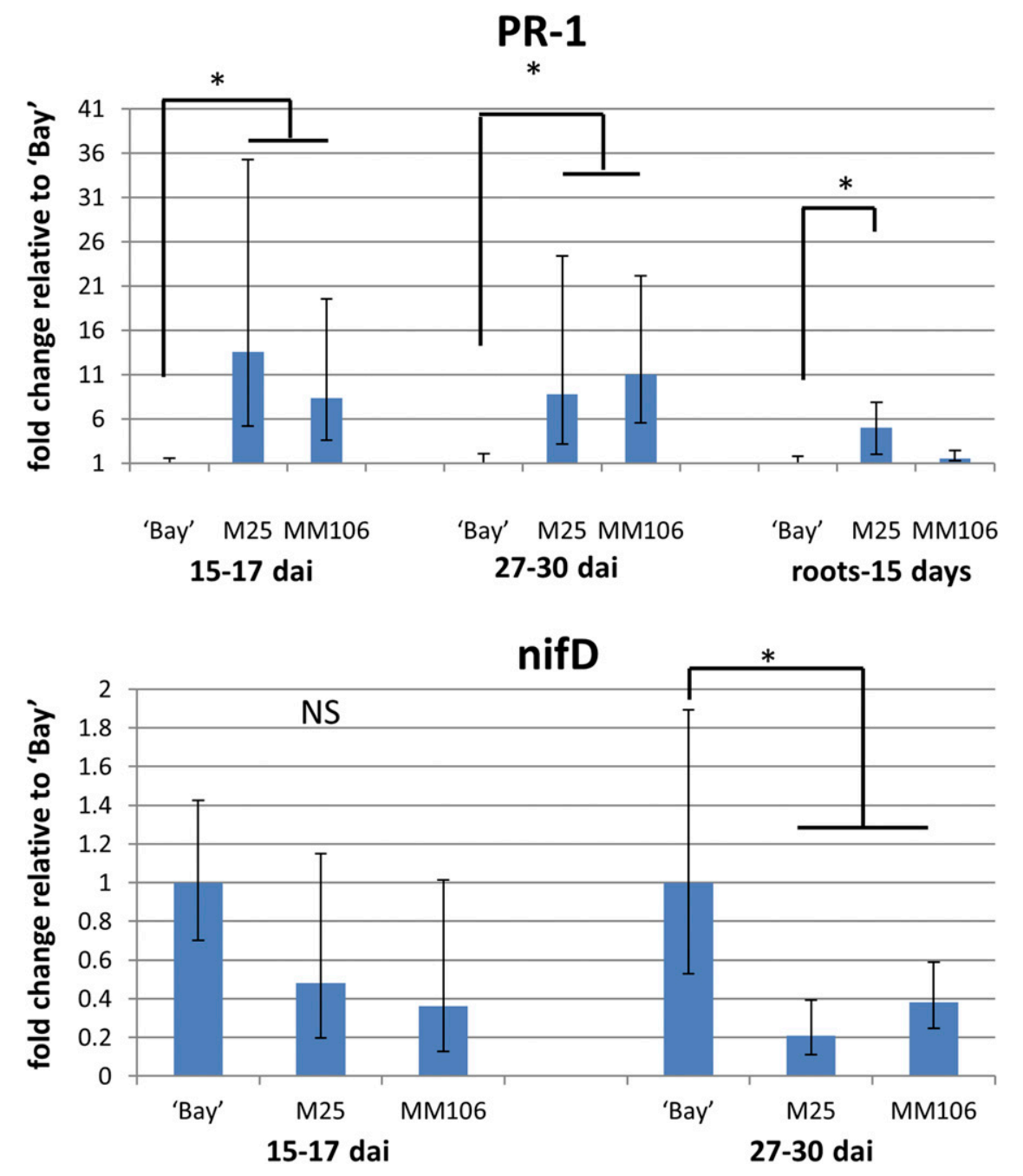

Fig. 8. Quantitative reverse transcription-polymerase chain reaction analysis of mRNA from soybean nodules at two developmental stages ( 15 and 30 days after inoculation) or from uninoculated roots (15 and 30 days after planting). The expression level of nitrogenase D (nifD) and Pathogenesis-Related 1 (PR-1) genes is presented relative to 'Bay'. Significant mRNA expression differences are indicated by an asterisk $(*)(P<0.05)$. 
with four other strains tested). The interaction between USDA110 and soybean 'Bay' proceeds along the well-documented sequence of nodule formation in soybean (Chatterjee et al. 1990) and culminates in the formation of nitrogen-fixing nodules. Inoculation of USDA110 on the roots of the sacpd-c mutant lines M25 and MM106 initially follows a similar developmental pattern as that of 'Bay'. However, at later stages, plant defenses are elicited that are characteristic of response to plant pathogens. The disintegration of internal cell structure, along with thickening of the cell walls and accumulation of phenolic deposits in the nodules of sacpd-c mutants, all point to the failure of the plant cells to recognize USDA110 as a symbiont, specifically at later nodule developmental stages. Unlike in 'Bay' nodules, in which the rhizobia are enclosed within a peribacteriod membrane (PBM), rhizobia in the nodules of sacpd-c mutants were often found free living, perhaps due to disintegration of the PBM.

One of the most striking outcomes of a sacpd-c mutation is the visual manifestation of water-soaked areas of soft necrotic tissue within nodules. The occurrence of watery and oozy tissue is reminiscent of the appearance of soft rot bacteria (e.g., Pectobacterium atrosepticum, P. carotovorum subsp. carotovorum, or Dickeya spp.) (Barras et al. 1994) that produce a variety of enzymes (pectinases, cellulases, proteases, phospholipases, and xylanases) that can cause degradation of plant cell-wall components (Barras et al. 1994). Although soft rot bacteria were not present in our nodulation assay system, the occurrence of soft rot is known to be promoted by low-oxygen conditions, such as those present in nitrogen-fixing nodules (Perombelon 2002). The appearance of watery tissue in nodules of sacpd-c mutants may suggest the possible involvement of cell wall-degrading enzymes, presumably expressed by USDA110. The possibility that cell wall-degrading enzymes are present in necrotic nodules of sacpd-c mutants awaits further investigation.

\section{The role of fatty acids in nitrogen-fixing nodules.}

Fatty acids are an important component of the PBM, and both saturated (16:0, palmitic acid; 18:0, stearic acid) and unsaturated fatty acids (16:1, palmitoleic acid; 18:1, oleic acid; 18:2, linoleic

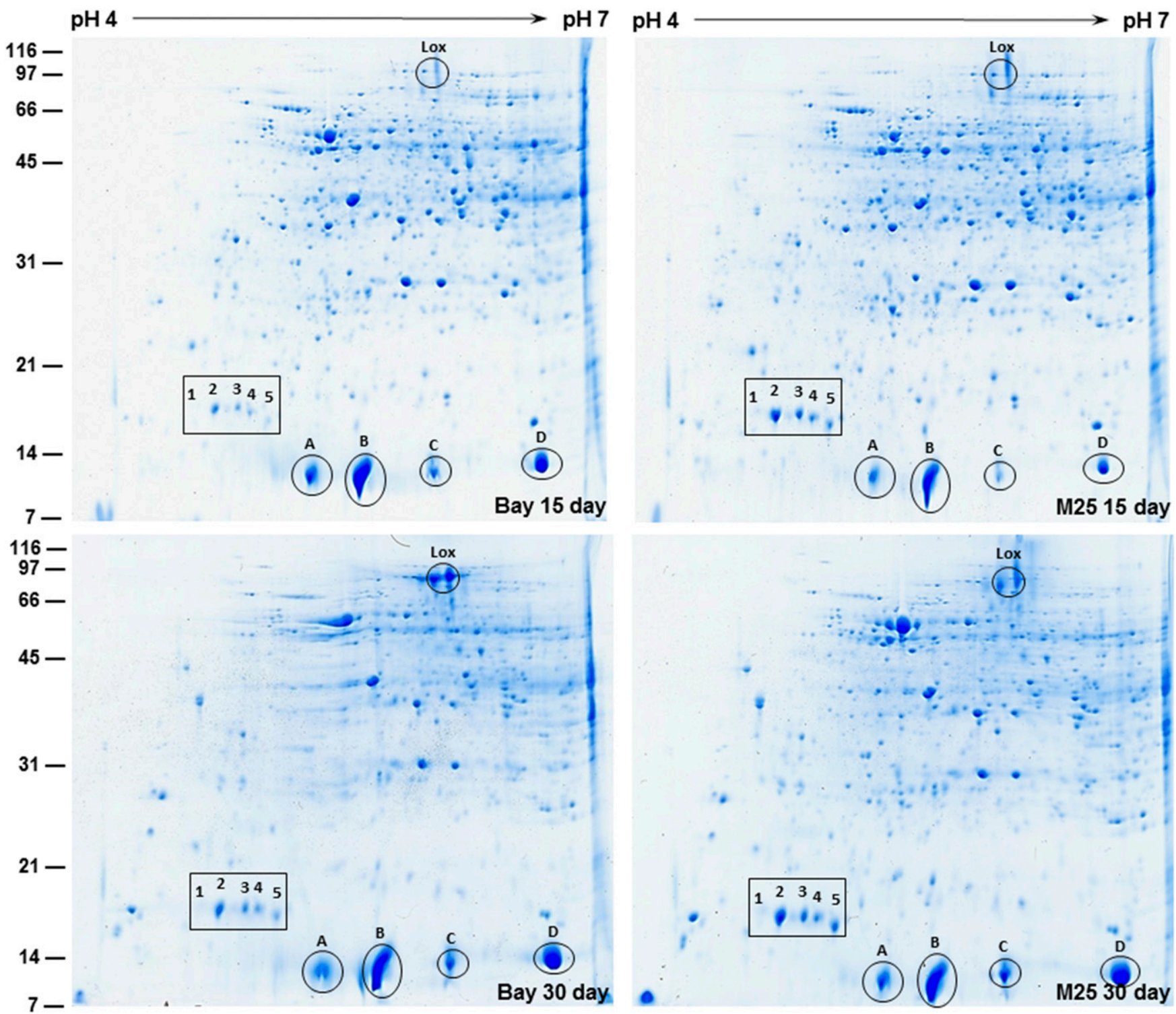

Fig. 9. Comparison of nodule cytosol proteins by two-dimensional gel electrophoresis. Nodule cytosol proteins isolated from soybean genotype 'Bay' and sacpd-c mutant line M25 at 15 and 30 days after inoculation were separated by isoelectric focusing (pH 4 to 7), followed by sodium dodecyl sulfatepolyacrylamide gel electrophoresis on a $15 \%$ gel. The proteins were visualized by staining the gel with colloidal Coomassie blue G-250. Protein spots showing differential accumulation are circled. The sizes of molecular weight markers in kilodaltons are shown on the left side of the figure. Lox $=$ lipoxygenase. Spots $\mathrm{A}, \mathrm{B}, \mathrm{C}$, and D refer to leghemoglobin; spots $1,2,3,4$, and 5 refer to pathogenesis-related proteins. 
acid; 18:3, $\alpha$-linolenic acid) are present in the PBM (Gaude et al. 2004). Previously, it has been shown that deletion of the $S A C P D-C$ locus causes an increase in the levels of stearic acid while lowering oleic acid levels in the nodules (Gillman et al. 2014). Even though we have not analyzed the fatty acid composition of the PBM in this study, the consistent alteration of fatty acids in multiple sacpd-c mutants from different backgrounds indicates that altered fatty acid composition is likely to be a contributing factor for the premature disruption of the PBM seen in the nodules of sacpd-c mutants.

Studies with Arabidopsis ssi2 mutant have highlighted the importance of fatty acids in defense response. The seven $S A C P D$

Table 2. Proteins identified from soybean nodules after two-dimensional-polyacrylamide gel electrophoresis separation and peptide mass fingerprinting (tandem mass spectrometry) ${ }^{\mathrm{z}}$

\begin{tabular}{|c|c|c|c|c|c|c|}
\hline Spot & Protein ID/accession no. & Score & \% Cov. & $M_{r}(E / T) p I(E / T)$ & Peptides matched (score) sequence & BLAST/accession no. \\
\hline \multirow[t]{2}{*}{1} & PR10-like protein (G. max) & 155 & 25 & $17,000 / 13,632$ & (57) M.GVFTFEDEINSPVAPATLYK.A & \\
\hline & NCBInr: NP_001238060.1 & & & $4.70 / 5.17$ & (98) K.AIEAYLLAHPDYN.- & \\
\hline \multirow[t]{6}{*}{2} & PR10-like protein (G. $\max$ ) & 372 & 55 & $17,000 / 13,632$ & (109) M.GVFTFEDEINSPVAPATLYK.A & \\
\hline & NCBInr: NP_001238060.1 & & & $4.80 / 5.17$ & (61) K.SVENVEGNGGPGTIK.K & \\
\hline & & & & & (17) K.KITFLEDGETK.F & \\
\hline & & & & & (45) K.ITFLEDGETK.F & \\
\hline & & & & & (46) K.GDAEPNQDELK.T & \\
\hline & & & & & (94) K.AIEAYLLÄHPDYN.- & \\
\hline \multirow[t]{4}{*}{3} & Uncharacterized protein & 221 & 31 & $17,000 / 16,702$ & (95) M.GIFTFEDEITSPVAPATLYK.A & Stress-induced protein \\
\hline & LOC100527097 (G. max) & & & $4.90 / 4.80$ & (36) K.ITFVEDGETK.F & SAM22 (G. $\max )$ \\
\hline & NCBInr: NP_001238655.1 & & & & (30) K.LTVEYQTK.G & NCBInr: NP_001236038.1 \\
\hline & & & & & (61) K.GDAQPNQDQLK.T & \\
\hline \multirow[t]{2}{*}{4} & Disease resistance response & 236 & 26 & $17,000 / 16,876$ & (148) M.GVFTFEDETTSTVAPAR.L & \\
\hline & $\begin{array}{l}\text { protein DRRG49-C (G. soja) } \\
\text { NCBInr: KHN12915.1 }\end{array}$ & & & $5.00 / 4.88$ & $\begin{array}{ll}\text { (55) } & \text { K.SVEIVEGNGGPGTIK.K } \\
\text { (33) } & \text { K.LTFVEDGQTK.Y }\end{array}$ & \\
\hline \multirow[t]{3}{*}{5} & Uncharacterized protein & 116 & 20 & $17,000 / 16,804$ & (62) M.GIFTFEDETTSPVAPATLYK.A & Stress-induced protein \\
\hline & LOC547916 (G. max) & & & $5.10 / 4.93$ & (54) K.AVEAYLLANPHYN.- & SAM22 (G. max) \\
\hline & NCBInr: NP_001236055.1 & & & & & NCBInr: NP_001236038.1 \\
\hline
\end{tabular}

${ }^{\mathrm{z}}$ Protein scores represent those scores obtained from Mascot searches. Molecular weight $\left(\mathrm{M}_{\mathrm{r}}\right)$ and isoelectric point $(\mathrm{pI})$ values are given as experimental/theoretical values (E/T). Peptides matched, \% coverage (\% Cov.), and accession numbers from the National Center for Biotechnology Information Nonredundant database are given. Peptide tolerance was $50 \mathrm{ppm}$.

Table 3. Quantitation of reactive oxygen species-related enzyme activity and lipid peroxidation in soybean nodules after infection by Bradyrhizobium japonicum USDA110

\begin{tabular}{|c|c|c|c|c|c|}
\hline Enzyme/measurement ${ }^{y}$ & Timepoint & 'Bay' & M25 & MM106 & ANOVA $^{z}$ \\
\hline \multirow[t]{2}{*}{ APX $\mu \mathrm{mols} \mathrm{min}^{-1} \mathrm{mg}^{-1}$} & 15 days & $1,098 \pm 50.9 \mathrm{a}$ & $1,512.5 \pm 67.2 \mathrm{~b}$ & $1,989.5 \pm 96.9 \mathrm{c}$ & $0.0029 * *$ \\
\hline & 30 days & $1,154.5 \pm 142.1 \mathrm{a}$ & $3,096.5 \pm 152 \mathrm{~b}$ & $3,323 \pm 421.4 \mathrm{~b}$ & $0.0072 * *$ \\
\hline \multirow{2}{*}{ CAT mmols $\mathrm{min}^{-1} \mathrm{mg}^{-1}$} & 15 days & $516 \pm 9.9 \mathrm{a}$ & $304 \pm 17 b$ & $324.5 \pm 4.9 \mathrm{~b}$ & $0.0006 * *$ \\
\hline & 30 days & $447 \pm 46.7 \mathrm{a}$ & $209 \pm 0 \mathrm{~b}$ & $148.5 \pm 41.7 \mathrm{~b}$ & $0.0074 * *$ \\
\hline \multirow[t]{2}{*}{ SOD units $\mathrm{mg}^{-1}$} & 15 days & $192 \pm 41 \mathrm{a}$ & $108 \pm 31.1 \mathrm{a}$ & $221 \pm 65.1 \mathrm{a}$ & $0.1923 \mathrm{NS}$ \\
\hline & 30 days & $1,86.5 \pm 14.8 \mathrm{a}$ & $328.5 \pm 4.9 b$ & $469.5 \pm 30.4 \mathrm{c}$ & $0.0017 * *$ \\
\hline \multirow[t]{2}{*}{ MDA nmols g ${ }^{-1}$} & 15 days & $121.5 \pm 57.3 \mathrm{a}$ & $74.5 \pm 30.4 \mathrm{a}$ & $73.4 \pm 1.9 \mathrm{a}$ & $0.4443 \mathrm{NS}$ \\
\hline & 30 days & $68.2 \pm 9.7 \mathrm{a}$ & $48.2 \pm 11.5 \mathrm{a}$ & $54.2 \pm 1.6 \mathrm{a}$ & $0.2093 \mathrm{NS}$ \\
\hline
\end{tabular}

${ }^{x}$ Values followed by the same letter are not significantly different.

y $\mathrm{APX}=$ ascorbate peroxidase; $\mathrm{CAT}=$ catalase; $\mathrm{SOD}=$ superoxide dismutase; and $\mathrm{MDA}=$ malondialdehyde.

${ }^{z}$ Analysis of variance (ANOVA) ( $P$ value). Asterisks indicate ANOVA significance at the $<0.05(*)$ or $<0.01(* *)$ level. NS indicates insignificant differences between means.

Table 4. Quantification of root phytohormones in nodules infected by Bradyrhizobium japonicum USDA110 (30 days after infection) and noninfected roots at 30 days after seed germination

\begin{tabular}{|c|c|c|c|c|c|}
\hline Tissue & Enzyme $^{x}$ & 'Bay'y & $\mathbf{M}^{2} 5^{\mathbf{y}}$ & MM106 $^{\mathbf{y}}$ & ANOVA $^{z}$ \\
\hline \multirow[t]{6}{*}{ Nodule } & ABA & $4.93 \pm 0.86$ & $5.57 \pm 3.61$ & $7.8 \pm 0.10$ & $0.3008 \mathrm{NS}$ \\
\hline & JA & $419.77 \pm 61.01 \mathrm{a}$ & $174 \pm 18.10 \mathrm{~b}$ & $327.63 \pm 128.26 \mathrm{ab}$ & $0.0290 *$ \\
\hline & JA-Ile & $2,010.43 \pm 541.26 \mathrm{a}$ & $290.60 \pm 45.25 b$ & $1,006.43 \pm 521.56 \mathrm{~b}$ & $0.0083 * *$ \\
\hline & OPDA & $2,799.33 \pm 384.73 a$ & $9,892.93 \pm 2,485.03 \mathrm{~b}$ & $9,655.43 \pm 1,789.29 b$ & $0.0044 * *$ \\
\hline & $\mathrm{JA}+\mathrm{OPDA}$ & $5,229.53 \pm 836.89 a$ & $10,357.50 \pm 2,542.17 b$ & $10,989.47 \pm 2,436.37 b$ & $0.0282 *$ \\
\hline & SA & $71.10 \pm 3.82$ & $58.73 \pm 0.90$ & $73.83 \pm 17.96$ & $0.2562 \mathrm{NS}$ \\
\hline \multirow[t]{6}{*}{ Root } & ABA & $199.65 \pm 61.22$ & $252.14 \pm 68.44$ & $222.54 \pm 13.43$ & $0.5800 \mathrm{NS}$ \\
\hline & JA & $3,551.63 \pm 434.51$ & $2,921.71 \pm 259.85$ & $2,623.71 \pm 73.12$ & $0.0530 \mathrm{NS}$ \\
\hline & JA-Ile & $35,165.84 \pm 3,994.66 \mathrm{a}$ & $28,983.03 \pm 1,365.67 \mathrm{~b}$ & $23,880.81 \pm 1,047.68 b$ & $0.01550^{*}$ \\
\hline & OPDA & $1,509.40 \pm 556.04$ & $1,452.15 \pm 443.02$ & $2,397.25 \pm 1,249.30$ & $0.3679 \mathrm{NS}$ \\
\hline & $\mathrm{JA}+\mathrm{OPDA}$ & $4,0226.88 \pm 4,362.94$ & $33,356.90 \pm 1,524.40$ & $20,893.46 \pm 13,971.66$ & $0.0790 \mathrm{NS}$ \\
\hline & SA & $7,583.22 \pm 1,529.25$ & $13,848.81 \pm 10,454.38$ & $5,089.58 \pm 3,340.75$ & $0.3924 \mathrm{NS}$ \\
\hline
\end{tabular}

\footnotetext{
$\mathrm{ABA}=$ abscisic acid; JA = jasmonic acid; Ile = isoleucine; OPDA = 12-oxophytodienoic acid; and SA = salicylic acid.

${ }^{\mathrm{y}}$ In nanograms per gram, $n=3$.

${ }^{\mathrm{z}}$ Analysis of variance (ANOVA); Prob $>$ F. Single or double asterisks ( $*$ or $* *$ ) indicate significance at the $<0.05$ or $<0.01$ level, respectively. Letters indicate the result of $t$ test comparison for significant ANOVA results.
} 
genes in Arabidopsis (Kachroo et al. 2007) are homologous to three subfunctionalized $S A C P D$ genes in soybean; $S A C P D-A$ and $S A C P D-B$ are ubiquitously expressed, whereas $S A C P D-C$ expression is restricted to developing seeds and nodules but is absent in vegetative tissues (Gillman et al. 2014; Zhang et al. 2008). In Arabidopsis, the desaturation of stearic acid (18:0) to oleic acid (18:1) is catalyzed by the stearoyl desaturase, which is encoded by the SSI2/FAB2 gene (Lightner et al. 1994; Shah et al. 2001). In contrast to the wild-type Arabidopsis, the ssi2 mutant accumulates higher amounts of 18:0 and decreased levels of 18:1 fatty acids (Kachroo et al. 2001). Interestingly, this mutant was unable to activate $P R$ gene expression after SA treatment but revealed higher expression of the resistance genes RPM1, SNC1, SSI4, RPP1, and RPS2 (Mandal et al. 2012). An additional feature of the ssi2 mutant is the development of spontaneous lesions on the leaves, associated with high levels of SA and constitutive expression of $P R-1, P R-2$, and $P R-5$ genes (Mandal et al. 2012).

\section{Soybean nodule and}

\section{root phytohormone profiles are distinct.}

Plant hormones have been demonstrated to have important roles in plant defense response (Kunkel and Brooks 2002). JA and ethylene are implicated as signal molecules in induced systemic resistance, while SA serves this function in systemic acquired resistance. JA is a signal molecule derived from linolenic acid, which is typically associated with defense against necrotrophic pathogens (Berrocal-Lobo et al. 2002; Plett et al. 2014). OPDA has been demonstrated to not directly interact with the COI1 complex in the same manner as other JA species (Thines et al. 2007) but has been reported to have independent signaling roles in a diverse range of distinct plant processes, including local defense responses (Wasternack and Strnad 2016).

We observed dramatic differences between root and nodule phytohormone levels for both mutant and wild-type lines (Table 4). ABA is approximately 40.5-fold lower in nodules as compared with roots of 'Bay' plants. JA, JA-Ile, and SA are likewise much lower in nodules as compared with roots (8.5fold, 17.5-fold, and 106.7-fold lower, respectively). In contrast, OPDA levels are approximately 1.9-fold higher in nodules as compared with roots. The phytohormone levels of roots are almost completely unchanged when the $S A C P D-C$ gene is deleted (except for a slight decrease in JA-Ile levels), whereas nodules of sacpd-c mutant lines show unique alterations inconsistent with the previous $S A C P D$ literature.

Interestingly, the levels of SA in sacpd-c mutant nodules were unchanged when compared with the parent soybean cultivar Bay. This is in stark contrast to Arabidopsis and soybean studies of vegetative tissues, in which loss of function for SACPD enzyme is associated with increased levels of SA (Kachroo et al. 2008; Shah et al. 2001). Moreover, nodules of sacpd-c mutant lines M25 and MM106 also have significant increases in $P R-1$ gene expression. In the sacpd-c mutant nodules, there is also a significant decrease in the levels of JA and JA-Ile but a dramatic increase in its biosynthetic precursor OPDA. These results were surprising in that we found that linolenic acid levels were higher in sacpd-c mutant lines (Gillman et al. 2014). One possible explanation for these seemingly disparate observations is that flux through the JA pathway is perturbed; increased linolenic acid leads to increased OPDA, but OPDA is not effectively converted to JA and downstream components (JA-Ile and others). Taken together, nodules have significantly different phytohormone composition as compared with root and vegetative tissues in general and markedly different phytohormone alterations due to loss of SACPD enzyme activity.

\section{Soybean nodule anitoxidant metabolism responses}

\section{to deletion of $S A C P D-C$.}

We observed increased antioxidant enzyme activities, APX, and SOD, in the nodules of sacpd-c mutants. Large amounts of ROS are produced during nitrogen fixation in the nodules (Matamoros et al. 2003), and plants employ antioxidant enzymes to minimize ROS-induced cell damage. In soybean, it has been shown that the large amounts of $\mathrm{H}_{2} \mathrm{O}_{2}$ accumulated in senescing nodules (Alesandrini et al. 2003), which results in oxidative damage of lipid, proteins, and DNA (Becana and Klucas 1992; Matamoros et al. 1999). Our observation that sacpd-c mutant nodules have elevated levels of APX and SOD in the nodules suggests the active upregulation of these enzymes in response to a perceived need for additional antioxidant defense. Earlier, it has been reported that a defect in the biosynthesis of linolenic acid resulted in the activation of $\mathrm{O}_{2}$-generating enzyme NADPH oxidase (Yaeno et al. 2004). Thus, the altered fatty acid composition encountered in sacpd-c mutant nodules could also result in the activation of APX and SOD.

It is interesting to note that the response of sacpd-c mutants to the symbiont USDA110 resembles soft-rot symptoms elaborated by the necrotrophic bacterial pathogen $P$. carotovorum subsp. carotovorum. In the case of sacpd-c mutants with altered fatty acid composition, the inhabitation by USDA110 has resulted in mounting a defense response at latter stages of nodule development. The profound histological changes, the dramatically higher accumulation of OPDA, increased PR protein accumulation, and increased antioxidant enzyme activities all point to the induction of plant immune response against USDA110 in nodules of sacpd-c mutants.

Previous studies have ascertained that sacpd mutants have elevated SA in vegetative tissues. Our study highlights the dramatic differences between root and nitrogen-fixing nodule phytohormone levels. We also establish a major role for SACPD-C enzyme activity as affecting the JA-independent signaling molecule OPDA, in proper soybean nodule maintenance, and attenuation of nodule defense responses.

\section{MATERIALS AND METHODS}

\section{Plant materials.}

Seeds of soybean 'Bay' were obtained from United States Department of Agriculture Agricultural Research Service Germplasm Resources Information Network collection. Two mutant lines, M25 and MM106, derived by X-ray mutagenesis of 'Bay' were provided by T. Anai (Faculty of Agriculture, Saga University, Japan) and the Legumebase seed repository (Miyazaki, Japan). Comparative genomic hybridization analysis has revealed that MM106 contains a large deletion $(-2.5 \mathrm{Mbp})$ that includes the $S A C P D-C$ locus. In contrast, M25 bears a single base deletion within exon 1 of $S A C P D-C$, resulting in a frameshift mutation (Gillman et al. 2014). These soybean lines were grown at the Bradford Research and Extension Center (Columbia, MO, U.S.A.) in 2011 and 2012, and the resulting seeds were used for the current study.

\section{Bacterial strains and growth conditions.}

Sinorhizobium fredii USDA191, USDAHH103 and Bradyrhizobium elkanii used in this study are from our laboratory collections. B. japonicum USDA 110 and a type 3 secretion system mutant line $\Delta 136$ (lacks a functional tts $I$ gene and several neighboring genes) were obtained from M. Göttfert (Institute of Genetics, Dresden University of Technology, Germany). Rhizobia were grown in yeast extract-mannitol (YEM) medium on a reciprocal shaker at $30^{\circ} \mathrm{C}$. 


\section{Nodulation assays.}

Surface-sterilized soybean seeds were germinated on $1 \%$ water agar plates in a $30^{\circ} \mathrm{C}$ incubator for 3 days. Cells of $\mathrm{Bra}$ dyrhizobium japonicum USDA110, B. japoniucum USDA110 $\Delta 136$, B. elkanii, Sinorhizobium fredii USDA191, and S. fredii HH103 grown in liquid YEM medium were harvested by centrifugation at $7,700 \times g$ for $15 \mathrm{~min}$. The resulting cell pellet was resuspended in liquid YEM, to a final concentration of $1 \times 10^{6}$ cells $/ \mathrm{ml}$. Roots of germinated soybean seedlings were immersed in 2-ml Eppendorf tubes containing the appropriate rhizobia, for 1 min. Following this, the seedlings were transferred to autoclaved Leonard jars containing vermiculite and were placed in a growth chamber that was maintained at a constant temperature of $28^{\circ} \mathrm{C}$, with a light intensity of $500 \mu \mathrm{mol}$ of photons per square meter per second, with a 12-h light period. Nodules were harvested at defined time periods and were used immediately, for anatomical studies, or frozen in liquid nitrogen, for RNA isolation and biochemical analysis.

\section{Response of sacpd-c mutants to SCN.}

Testing for resistance to $\mathrm{SCN}$ (race 3/HG type7) was done at the ACTS, Inc. laboratory (Carrol, IA, U.S.A.). Full details on the greenhouse screening method were published (Niblack et al. 2009). Briefly, seed were germinated and were then moved to a sterile soil and sand mixture in a cone container, with each cone containing a single seedling. After 24 h, 3,000 SCN eggs (race 3/HG type7) were added to each container. Plants were then grown for 31 days, and at the end of the period, plants were removed from the soil and sand mixture. Roots were washed over nested sieves, and SCN cysts were counted, using a stereo microscope. Two susceptible check lines (Williams 82, Lee 74) and seven resistant lines (Peking, PI 88788, PI 90763, PI 437654, PI 209332, PI 89772, and PI 548316) were also included as controls. A total of six replicates were done for each genotype, and mean cyst counts were calculated. Mean counts were converted to Female indexes ( $\mathrm{FI}=100 \times$ average number of cysts/number of cysts on two susceptible checks). Samples with FI values $<5$ were considered to be resistant and $<30$ were considered to be moderately resistant.

\section{Light and transmission electron microscopy.}

The procedure for embedding soybean nodules in paraffin for light microscopy has been described previously (Krishnan 2002). Paraffin-embedded nodules were sectioned with a microtome to a thickness of $10 \mu \mathrm{m}$ and were stained with hematoxylin and eosin. For ultrastructural studies, soybean nodules harvested at 7, 15, and 30 dai were cut into 2- to 4-mm pieces with a razor blade. They were immediately fixed in buffered $2.5 \%$ glutaraldehyde $(\mathrm{pH} 7.2 ; 50 \mathrm{mM}$ sodium phosphate) at room temperature for $4 \mathrm{~h}$. The tissue samples were washed four times, at 15-min intervals, with $50 \mathrm{mM}$ phosphate buffer $(\mathrm{pH}$ 7.2) and were post-fixed with $2 \%$ aqueous osmium tetroxide for $1 \mathrm{~h}$ at room temperature. After extensive rinses in distilled water, the samples were dehydrated in a graded acetone series and were infiltrated with Spurr's resin. Thin sections were cut with a diamond knife and were collected on uncoated copper grids, were stained with $0.5 \%$ aqueous uranyl acetate and $0.4 \%$ aqueous lead citrate, and were viewed with a JEOL JEM 100B (Tokyo) electron microscope at $100 \mathrm{kV}$.

\section{One and two-dimensional gel electrophoresis and image analysis.}

For one-dimensional electrophoretic analysis, $50 \mathrm{mg}$ of nodules harvested at 15 and 30 dai were ground into a fine powder with a mortar and pestle. The nodule powder was extracted with $1 \mathrm{ml}$ of SDS-PAGE sample buffer containing protease inhibitor cocktail. The solution was clarified at $16,100 \times g$ for $10 \mathrm{~min}$.
Supernatant was removed and boiled for $5 \mathrm{~min}$, and $10-\mu \mathrm{l}$ aliquots were used for electrophoresis. One-dimensional separation followed the method of Laemmli (1970) using 13 to $15 \% \mathrm{~T}$ gels run using a Mini250 apparatus (GE Healthcare, Piscataway, NJ, U.S.A.). Separation was achieved with a constant $20 \mathrm{~mA}$ per gel and a typical run time of $1.2 \mathrm{~h}$. Gels were removed from the cassette and were placed immediately in Coomassie staining solution.

\section{Two-dimensional electrophoresis.}

For two-dimensional electrophoretic analysis, nodules $(250 \mathrm{mg})$ were placed into a prechilled mortar and pestle with a small amount of acid washed sand and $5 \mathrm{ml}$ of $100 \mathrm{mM}$ Tris-Cl, $\mathrm{pH} 8.8$, containing $17 \% \mathrm{wt} / \mathrm{vol}$ sucrose, $0.4 \% \mathrm{vol} / \mathrm{vol} \beta$-mercaptoethanol and protease inhibitor cocktail. Mixture was ground into a liquid and was placed on ice. Solution was vortexed heavily and was centrifuged at $400 \times g$ for $10 \mathrm{~min}$ at $5^{\circ} \mathrm{C}$. Supernatant was placed into a fresh tube and was centrifuged at $8,000 \times g$ for $20 \mathrm{~min}$ at $5^{\circ} \mathrm{C}$. Pellet was discarded and supernatant was placed into a fresh tube and was placed on ice. This nodule cytosol solution was adjusted to $0.9 \mathrm{M}$ sucrose, and an equal volume of Tris-equilibrated phenol was then added, mixing vigorously for $30 \mathrm{~min}$ at $25^{\circ} \mathrm{C}$. The phenolic phase was then obtained by centrifugation at $5,000 \times g$ for $20 \mathrm{~min}$ at $25^{\circ} \mathrm{C}$ in a swing-bucket rotor. The upper phenolic phase was removed and was added to eight volumes of freshly prepared $100 \%$ methanol with $0.1 \mathrm{M}$ ammonium acetate. Protein precipitation progressed for $2 \mathrm{~h}$ at $-80^{\circ} \mathrm{C}$ and was followed by centrifugation at $8,000 \times g$ for $20 \mathrm{~min}$ at $4^{\circ} \mathrm{C}$. Supernatant was discarded and protein pellet was suspended vigorously in a freshly prepared solution of $100 \%$ methanol, with $0.1 \mathrm{M}$ ammonium acetate containing $0.01 \mathrm{M}$ dithiothreitol (DTT) (chilled to $-20^{\circ} \mathrm{C}$ ). Washing of the insoluble proteins was repeated two times with the same solution, with incubation at $-20^{\circ} \mathrm{C}$ for $20 \mathrm{~min}$ (between centrifugations), followed by centrifugation at $8,000 \times g$ for $10 \mathrm{~min}$ at $4^{\circ} \mathrm{C}$ between each vigorous wash step. Washing of the insoluble proteins was repeated three additional times with freshly prepared solution of $100 \%$ acetone containing $0.01 \mathrm{M} \mathrm{DTT}$, with incubation at $-20^{\circ} \mathrm{C}$ for $20 \mathrm{~min}$, followed by centrifugation at $8,000 \times g$ for $10 \mathrm{~min}$ at $4^{\circ} \mathrm{C}$ between each vigorous wash step. Following the final wash, the protein pellet was allowed to air-dry and proteins were then dissolved in a small volume of $7 \mathrm{M}$ urea, $2 \mathrm{M}$ thiourea, $1 \% \mathrm{wt} / \mathrm{vol} \mathrm{CHAPS}$, and $2 \% \mathrm{wt} / \mathrm{vol} \mathrm{C7BzO}$.

Protein estimation was performed following the method of Bradford (1976), and $400 \mu \mathrm{g}$ of protein sample was loaded per isoelectric focusing strip, using overnight in-gel rehydration. Isoelectric focusing and second-dimension SDS-PAGE was carried out as described earlier (Krishnan et al. 2009). Following electrophoresis, the gels were fixed in 5:4:1 methanol/water/acetic acid for $30 \mathrm{~min}$, followed by two brief rinses in water, and were stained in a Coomassie G-250 solution overnight. Gels were scanned using an Epson V700 Perfection scanner controlled through Adobe Photoshop. Stained gels were analyzed for proteome differences using Delta2D v3.6 image analysis software (Decodon, Greifswald, Germany). Parameters were set to maximize detection of every spot and images were globally warped to a control image, using exact spot matching and reference proteins that were present in all gels. Since nearly all protein spots were kept for calculation purposes and the total quantity of all spots on the gel is $100 \%$, the relative quantity of the spot gave an accurate determination of the percentage change between comparisons.

RNA extraction, qRT-PCR, and statistical analysis.

Two stages of soybean nodule formation, 15 and 30 dai, were chosen for qRT-PCR analysis. For each genotype and 
timepoint, three to five nodules were pooled from each of four biological replicates. Uninoculated roots 15 and 30 days old (two to three biological replicates) were also included in this analysis. RNA was purified using a Zymo Direct-zol kit (Zymo, Irvine, CA, U.S.A.). qRT-PCR was carried out, as previously described (Kim et al. 2013), using $0.5 \mu \mathrm{g}$ of Dnase-treated total RNA for nodules and $75 \mathrm{ng}$ of Dnase-treated total RNA for unninoculated roots. An aliquot of $1 / 20$ of the total RT reaction was used for qRT-PCR with SYBR qPCR premix (Qiagen, Valencia, CA, U.S.A.) and an LC480 II instrument (Roche Applied Sciences, Indianapolis, IN, U.S.A.). PR-1-specific oligonu-

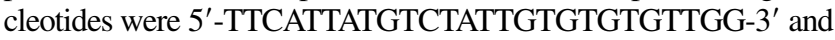
5'-AAACTATATTTGGAACACCAACCTGT-3' and nitrogenase D oligonucleotides were 5'-ACCAACAGCGTCGCAGAAATCA-3' and 5'-TTGGTGCACGTTGAGGTGCTT-3'. Amplification curves were compared via the cycle threshold $\left(\Delta \Delta \mathrm{C}_{\mathrm{T}}\right)$ method (Livak and Schmittgen 2001), using a cons6 (Libault et al. 2008) gene as a reference gene, and were converted to fold changes relative to 'Bay' samples. JMP version 11.1 software (SAS Institute Inc., Cary, NC, U.S.A.) was used for one-way analysis of variance (ANOVA) tests to compare mean $\Delta \mathrm{C}_{\mathrm{T}}$ values. When ANOVA tests displayed significant differences $(P<$ $0.05)$, a student's $t$ test was performed ( $\alpha=0.05$ significance level cutoff) to compare samples within genotypes at each stage.

\section{Measurement of antioxidant enzymes.}

Nodule tissue (100 mg) was weighed and ground in prechilled mortar and pestle, and proteins extracted with $1 \mathrm{ml}$ of ice cold $50 \mathrm{mM}$ sodium phosphate buffer, $\mathrm{pH} 7.0$ containing $17 \% \mathrm{wt} / \mathrm{vol}$ sucrose. This was followed by 2 min of heavy vortexing at $4^{\circ} \mathrm{C}$. Extraction was clarified at $400 \times g$ for $10 \mathrm{~min}$ at $5^{\circ} \mathrm{C}$ and supernatant was further clarified at $8,000 \times g$ for $20 \mathrm{~min}$ at $4^{\circ} \mathrm{C}$ to remove bacteroids. Protein concentration was determined using the method of Bradford (1976). The APX activity assay was based on the rate of ascorbate oxidation (decrease in optical density of ascorbate at $290 \mathrm{~nm}$ ) and was monitored over time. Assay $(1 \mathrm{ml})$ contained $50 \mathrm{mM}$ sodium phosphate buffer, $\mathrm{pH} 7.0$, and nodule tissue extract (time $=0$ ), then $0.1 \mathrm{mM} \mathrm{H}_{2} \mathrm{O}_{2}$ and $0.5 \mathrm{mM}$ sodium ascorbate was added to begin the assay. An extinction coefficient of $2.8 \mathrm{mM}^{-1} \mathrm{~cm}^{-1}$ for ascorbate was used to calculate activity. The CAT activity assay was based on the rate of decomposition of hydrogen peroxide (decrease in optical density of $\mathrm{H}_{2} \mathrm{O}_{2}$ ) and was monitored over time at $240 \mathrm{~nm}$. The assay $(1 \mathrm{ml})$ contained $50 \mathrm{mM}$ sodium phosphate buffer, $\mathrm{pH} 7.0$, and nodule tissue extract (time $=0$ ), then, $0.1 \% \mathrm{H}_{2} \mathrm{O}_{2}$ was added to begin the assay. An extinction coefficient for $\mathrm{H}_{2} \mathrm{O}_{2}$ of $0.04 \mathrm{mM}^{-1} \mathrm{~cm}^{-1}$ was used to calculate activity. The SOD activity assay was based on the inhibition of nitro-blue tetrazolium (NBT) reduction, monitored over time at $560 \mathrm{~nm}$. Illumination of riboflavin in the presence of oxygen and the electron donor methionine generates superoxide anions, which, in turn, causes reduction of NBT by superoxide radicals, forming the blue-colored formazen. The assay $(1 \mathrm{ml})$ contained $40 \mathrm{mM}$ sodium phosphate buffer, $\mathrm{pH} 7.8,13 \mathrm{mM}$ methionine, $75 \mu \mathrm{M}$ NBT, and $2 \mu \mathrm{M}$ riboflavin. Nodule tissue extract was added to assay mix in a glass tube (time $=0$ ) and the tube was placed within $15 \mathrm{~cm}$ of a fluorescent light. Spectrophotometric readings at $560 \mathrm{~nm}$ were taken every $5 \mathrm{~min}$ for a total reaction time of $20 \mathrm{~min}$. One unit of SOD activity is the amount of enzyme required to inhibit the reduction of NBT by $50 \%$ under the specified conditions.

\section{Hormone detection and analysis.}

Freshly isolated nodule samples were flash-frozen with liquid nitrogen and were shipped on dry ice to the Donald Danforth Plant Science Center for plant hormone analysis. Acidic plant hormones (SA, ABA, JA, JA-Ile, and OPDA) were extracted from flash-frozen tissues and samples were homogenized with $900 \mu \mathrm{l}$ of ice-cold methanol/acetonitrile (1:1 vol/vol). Samples were then spiked with a mixture of deuterium-labeled standards (D5SA, D6ABA, D2JA, D5IAA) at $2.5 \mu \mathrm{M}$ each, and were spiked at the beginning of the extraction, using a TissueLyserII ( $2 \mathrm{~min}, 15 \mathrm{~Hz} / \mathrm{s})$. Following homogenization, samples were then centrifuged at $16,000 \times g$ for 5 min at $4^{\circ} \mathrm{C}$. The supernatant was transferred to a fresh tube and pellets were re-extracted as described above. Both supernatants were combined and were dried in a speed vacuum, were then redissolved in $200 \mu \mathrm{l}$ of $30 \%$ methanol. Redissolved samples were recentrifuged and were transferred to a fresh vial before LC-MS/MS analysis.

An Eksigent LC system with an AB Sciex 6500 QTRAP mass spectrometer equipped with a TurboIonSpray electrospray ion source was used for hormone analysis.

For LC separation, an Acquity BEH $1.7 \mu \mathrm{m} \mathrm{C} 18$ column $(1 \times$ $100 \mathrm{~mm}$; Waters, Milford, MA, U.S.A.) was used. Flow rate was set at $1 \mathrm{ml} \mathrm{min}^{-1}$, and the gradient consisted of $80 \%$ solvent A $(0.1 \%$ [vol/vol] formic acid in water $)$, held for $4 \mathrm{~min}$, then switched to $70 \%$ solvent B $(100 \%$ acetonitrile [vol/vol] with $0.1 \%$ formic acid [ $\mathrm{vol} / \mathrm{vol}]$ ) in $3 \mathrm{~min}$, then, to $95 \% \mathrm{~B}$ in $0.5 \mathrm{~min}$ and was held for $4.5 \mathrm{~min}$. The LC was then ramped to initial solvent ( $80 \%$ solvent $\mathrm{A})$ in $0.5 \mathrm{~min}$ and re-equilibrated for three additional minutes. A series of standard samples containing different concentrations of hormones was prepared for quantitation. Sample peak area was first normalized as was done for standard samples and was then quantified according to the standard curve.

LC-MS/MS parameters were set as follows: source gas 1, 50 arbitrary units (a.u.); curtain gas, 25 a.u.; source gas 2, 50 a.u.; collision activated dissociation was on high; interface heater, on; temperature, $550^{\circ} \mathrm{C}$; ion spray voltage was set at $-4,500$. Both of the quadrupoles (Q1 and Q3) were set to unit resolution. The 6500 QTRAP mass spectrometer was calibrated and tuned according to recommendations of the manufacturer. Analysis software, version 1.6.2, controlled sample acquisition and data analysis. Hormones were detected using multiple reaction monitoring transitions, optimized using previously run standards and with deuterium-labeled standards.

\section{ACKNOWLEDGMENTS}

This study was partially funded by a grant from the United Soybean Board (project number 1420-632-6605). The authors acknowledge T. Anai and Legumebase for providing lines MM106, M25, and KK2. Mention of a trademark, vendor, or proprietary product does not constitute a guarantee or warranty of the product by the United States Department of Agriculture (USDA) and does not imply its approval to the exclusion of other products or vendors that may also be suitable. The USDA Agricultural Research Service, Midwest Area is an equal opportunity, affirmative action employer and all agency services are available without discrimination.

\section{LITERATURE CITED}

Akagi, H., Baba, T., Shimada, H., and Fujimura, T. 1995. Nucleotide sequence of a stearoyl-acyl carrier protein desaturase cDNA from developing seeds of rice. Plant Physiol. 108:845-846.

Alesandrini, F., Mathis, R., Van de Sype, G., Hérouart, D., and Puppo, A. 2003. Possible roles for a cysteine protease and hydrogen peroxide in soybean nodule development and senescence. New Phytol. 158: 131-138.

Barras, F., Van Gijsegem, F., and Chatterjee, A. 1994. Extracellular enzymes and pathogenesis of soft rot Erwinia. Ann. Rev. Phytopathol. 32:201-234.

Becana, M., and Klucas, R. V. 1992. Transition metals in legume root nodules: Iron-dependent free radical production increases during nodule senescence. Proc. Natl. Acad. Sci. U.S.A. 89:8958-8962. 
Berrocal-Lobo, M., Molina, A., and Solano, R. 2002. Constitutive expression of ETHYLENE-RESPONSE-FACTOR1 in Arabidopsis confers resistance to several necrotrophic fungi. Plant J. 29:23-32.

Boersma, J. G., Gillman, J. D., Bilyeu, K. D., Ablett, G. R., Grainger, C., and Rajcan, I. 2012. New mutations in a delta-9-stearoyl-acyl carrier protein desaturase gene associated with enhanced stearic acid levels in soybean seed. Crop Sci. 52:1736-1742.

Bosch, M., Wright, L. P., Gershenzon, J., Wasternack, C., Hause, B., Schaller, A., and Stintzi, A. 2014. Jasmonic acid and its precursor 12 oxophytodienoic acid control different aspects of constitutive and induced herbivore defenses in tomato. Plant Physiol. 166:396-410.

Bradford, M. M. 1976. A rapid and sensitive method for the quantitation of microgram quantities of protein utilizing the principle of protein-dye binding. Anal. Biochem. 72:248-254.

Brechenmacher, L., Lei, Z., Libault, M., Findley, S., Sugawara, M., Sadowsky, M. J., Sumner, L. W., and Stacey, G. 2010. Soybean metabolites regulated in root hairs in response to the symbiotic bacterium Bradyrhizobium japonicum. Plant Physiol. 153:1808-1822.

Chandra-Shekara, A. C., Venugopal, S. C., Barman, S. R., Kachroo, A., and Kachroo, P. 2007. Plastidial fatty acid levels regulate resistance genedependent defense signaling in Arabidopsis. Proc. Natl. Acad. Sci. U.S.A. 104:7277-7282.

Chatterjee, A., Balatti, P. A., Gibbons, W., and Pueppke, S. G. 1990. Interaction of Rhizobium fredii USDA257 and nodulation mutants derived from it with the agronomically improved soybean cultivar McCall. Planta 180:303-311.

Colebatch, G., Desbrosses, G., Ott, T., Krusell, L., Montanari, O., Kloska, S., Kopka, J., and Udvardi, M. K. 2004. Global changes in transcription orchestrate metabolic differentiation during symbiotic nitrogen fixation in Lotus japonicus. Plant J. 39:487-512.

Desbrosses, G. G., Kopka, J., and Udvardi, M. K. 2005. Lotus japonicus metabolic profiling. Development of gas chromatography-mass spectrometry resources for the study of plant-microbe interactions. Plant Physiol. 137:1302-1318.

Durner, J., Shah, J., and Klessig, D. F. 1997. Salicylic acid and disease resistance in plants. Trends Plant Sci. 2:266-274.

Emerich, D. W., and Krishnan, H. B. 2014. Symbiosomes: Temporary moonlighting organelles. Biochem. J. 460:1-11.

Gaude, N., Tippmann, H., Flemetakis, E., Katinakis, P., Udvardi, M., and Dörmann, P. 2004. The galactolipid digalactosyldiacylglycerol accumulates in the peribacteroid membrane of nitrogen-fixing nodules of soybean and Lotus. J. Biol. Chem. 279:34624-34630.

Gillman, J. D., Stacey, M. G., Cui, Y., Berg, H. R., and Stacey, G. 2014. Deletions of the $S A C P D-C$ locus elevate seed stearic acid levels but also result in fatty acid and morphological alterations in nitrogen fixing nodules. BMC Plant Biol. 14:143.

Kachroo, A., Fu, D.-Q., Havens, W., Navarre, D., Kachroo, P., and Ghabrial, S. A. 2008. An oleic acid-mediated pathway induces constitutive defense signaling and enhanced resistance to multiple pathogens in soybean. Mol. Plant-Microbe Interact. 21:564-575.

Kachroo, A., Lapchyk, L., Fukushige, H., Hildebrand, D., Klessig, D., and Kachroo, P. 2003b. Plastidial fatty acid signaling modulates salicylic acid- and jasmonic acid-mediated defense pathways in the Arabidopsis ssi2 mutant. Plant Cell 15:2952-2965.

Kachroo, A., Shanklin, J., Whittle, E., Lapchyk, L., Hildebrand, D., and Kachroo, P. 2007. The Arabidopsis stearoyl-acyl carrier protein-desaturase family and the contribution of leaf isoforms to oleic acid synthesis. Plant Mol. Biol. 63:257-271.

Kachroo, A., Venugopal, S. C., Lapchyk, L., Falcone, D., Hildebrand, D., and Kachroo, P. 2004. Oleic acid levels regulated by glycerolipid metabolism modulate defense gene expression in Arabidopsis. Proc. Natl. Acad. Sci. U.S.A. 101:5152-5157.

Kachroo, P., Kachroo, A., Lapchyk, L., Hildebrand, D., and Klessig, D. F 2003a. Restoration of defective cross talk in ssi2 mutants: Role of salicylic acid, jasmonic acid, and fatty acids in SSI2-mediated signaling. Mol. Plant-Microbe Interact. 16:1022-1029.

Kachroo, P., Shanklin, J., Shah, J., Whittle, E. J., and Klessig, D. F. 2001. A fatty acid desaturase modulates the activation of defense signaling pathways in plants. Proc. Natl. Acad. Sci. U.S.A. 98:9448-9453.

Kachroo, P., Venugopal, S. C., Navarre, D. A., Lapchyk, L., and Kachroo, A. 2005. Role of salicylic acid and fatty acid desaturation pathways in ssi2-mediated signaling. Plant Physiol. 139:1717-1735.

Kim, W.-S., Gillman, J. G., and Krishnan, H. B. 2013. Identification of a plant introduction soybean line with genetic lesions affecting two distinct glycinin subunits and evaluation of impacts on protein content and composition. Mol. Breed. 32:291-298.

Krishnan, H. B. 2002. NolX of Sinorhizobium fredii USDA257, a type IIIsecreted protein involved in host range determination, is localized in the infection threads of cowpea (Vigna unguiculata [L.] Walp) and soybean (Glycine max [L.] Merr.) nodules. J. Bacteriol. 184:831-839.

Krishnan, H. B., Oehrle, N. W., and Natarajan, S. S. 2009. A rapid and simple procedure for the depletion of abundant storage proteins from legume seeds to advance proteome analysis: A case study using Glycine max. Proteomics 9:3174-3188.

Kunkel, B. N., and Brooks, D. M. 2002. Cross talk between signaling pathways in pathogen defense. Curr. Opin. Plant Biol. 5:325-331.

Laemmli, U. K. 1970. Cleavage of structural proteins during the assembly of the head of bacteriophage T4. Nature 227:680-685.

Libault, M., Thibivilliers, S., Bilgin, D. D., Radwan, O., Benitez, M., Clough, S. J., and Stacey, G. 2008. Identification of four soybean reference genes for gene expression normalization. Plant Genome 1:44-54.

Lightner, J., Wu, J., and Browse, J. 1994. A mutant of Arabidopsis with increased levels of stearic acid. Plant Physiol. 106:1443-1451.

Livak, K. J., and Schmittgen, T. D. 2001. Analysis of relative gene expression data using real-time quantitative PCR and the $2^{-\Delta \Delta C(T)}$ method. Methods 25:402-408.

Long, S. R. 1996. Rhizobium symbiosis: Nod factors in perspective. Plant Cell 8:1885-1898.

Mandal, M. K., Chandra-Shekara, A. C., Jeong, R. D., Yu, K., Zhu, S., Chanda, B., Navarre, D., Kachroo, A., and Kachroo, P. 2012. Oleic aciddependent modulation of NITRIC OXIDE ASSOCIATED1 protein levels regulates nitric oxide-mediated defense signaling in Arabidopsis. Plant Cell 24:1654-1674.

Matamoros, M. A., Baird, L. M., Escuredo, P. R., Dalton, D. A., Minchin, F. R., Iturbe-Ormaetxe, I., Rubio, M. C., Moran, J. F., Gordon, A. J., and Becana, M. 1999. Stress-induced legume root nodule senescence. Physiological, biochemical, and structural alterations. Plant Physiol. 121:97-112.

Matamoros, M. A., Dalton, D. A., Ramos, J., Clemente, M. R., Rubio, M. C. and Becana, M. 2003. Biochemistry and molecular biology of antioxidants in the rhizobia-legume symbiosis. Plant Physiol. 133:499-509.

Mithöfer, A. 2002. Suppression of plant defence in rhizobia-legume symbiosis. Trends Plant Sci. 7:440-444.

Niblack, T., Tylka, G. L., Arelli, P., Bond, J., Diers, B., Donald, P., Faghihi, J., Ferris, V. R., Gallo, K., Heinz, R. D., Lopez-Nicora, H., Von Qualen, R., Welacky, T., and Wilcox, J. 2009. A standard greenhouse method for assessing soybean cyst nematode resistance in soybean: SCE08 (standardized cyst evaluation 2008). Plant Health Prog. doi:10.1094/PHP-20090513-01-RV. Published online.

Nishida, I., Beppu, T., Matsuo, T., and Murata, N. 1992. Nucleotide sequence of a cDNA clone encoding a precursor to stearoyl-(acylcarrier-protein) desaturase from spinach, Spinacia oleracea. Plant Mol Biol. 19:711-713.

Oehrle, N. W., Sarma, A. D., Waters, J. K., and Emerich, D. W. 2008. Proteomic analysis of soybean nodule cytosol. Phytochemistry 69:2426-2438.

Oliveira, J. T. A., Barreto, A. L. H., Vasconcelos, I. M., Eloy, Y. R. G., Gondim, D. M. F., Fernandes, C. F., and Freire-Filho, F. R. 2014. Role of antioxidant enzymes, hydrogen peroxide and PR-proteins in the compatible and incompatible interactions of cowpea (Vigna unguiculata) genotypes with the fungus Colletotrichum gloeosporioides. J. Plant Physiol. Pathol. 2:3.

Perombelon, M. C. M. 2002. Potato diseases caused by soft rot erwinias: An overview of pathogenesis. Plant Pathol. 51:1-12.

Perret, X., Staehelin, C., and Broughton, W. J. 2000. Molecular basis of symbiotic promiscuity. Microbiol. Mol. Biol. Rev. 64:180-201.

Pieterse, C. M., Leon-Reyes, A., Van der Ent, S., and Van Wees, S. C. 2009. Networking by small-molecule hormones in plant immunity. Nat. Chem. Biol. 5:308-316.

Plett, J. M., Khachane, A., Ouassou, M., Sundberg, B., Kohler, A., and Martin, F. 2014. Ethylene and jasmonic acid act as negative modulators during mutualistic symbiosis between Laccaria bicolor and Populus roots. New Phytol. 202:270-286.

Relić, B., Perret, X., Estrada-García, M. T., Kopcinska, J., Golinowski, W., Krishnan, H. B., Pueppke, S. G., and Broughton, W. J. 1994. Nod factors of Rhizobium are a key to the legume door. Mol. Microbiol. 13: 171-179.

Roth, L. E., and Stacey, G. 1989. Bacterium release into host cells of nitrogen-fixing soybean nodules: The symbiosome membrane comes from three sources. Eur. J. Cell Biol. 49:13-23.

Ryals, J. A., Neuenschwander, U. H., Willits, M. G., Molina, A., Steiner, H.-Y., and Hunt, M. D. 1996. Systemic acquired resistance. Plant Cell 8: 1809-1819.

Shah, J., Kachroo, P., Nandi, A., and Klessig, D. F. 2001. A recessive mutation in the Arabidopsis SSI2 gene confers SA- and NPRIindependent expression of $P R$ genes and resistance against bacterial and oomycete pathogens. Plant J. 25:563-574. 
Shanklin, J., and Cahoon, E. B. 1998. Desaturation and related modification of fatty acids. Annu. Rev. Plant Physiol. Plant Mol. Biol. 49:611-641.

Shanklin, J., and Somerville, C. 1991. Stearoyl-acyl-carrier-protein desaturase from higher plants is structurally unrelated to the animal and fungal homologs. Proc. Natl. Acad. Sci. U.S.A. 88:2510-2514.

Taylor, M. A., Smith, S. B., Davies, H. V., and Burch, L. R. 1992. The primary structure of a cDNA clone of the stearoyl-acyl carrier protein desaturase gene from potato (Solanum tuberosum L.). Plant Physiol. 100: 533-534.

Thines, B., Katsir, L., Melotto, M., Niu, Y., Mandaokar, A., Liu, G., Nomura, K., He, S. Y., Howe, G. A., and Browse, J. 2007. JAZ repressor proteins are targets of the $\mathrm{SCF}(\mathrm{COI} 1)$ complex during jasmonate signalling. Nature 448:661-665.

Thompson, G. A., Scherer, D. E., Foxall-Van Aken, S., Kenny, J. W., Young, H. L., Shintani, D. K., Kridl, J. C., and Knauf, V. C. 1991. Primary structures of the precursor and mature forms of stearoyl-acyl carrier protein desaturase from safflower embryos and requirement of ferredoxin for enzyme activity. Proc. Natl. Acad. Sci. U.S.A. 88: 2578-2582.
Vance, C. P. 2001. Symbiotic nitrogen fixation and phosphorus acquisition Plant nutrition in a world of declining renewable resources. Plant Physiol. 127:390-397.

Vasse, J., de Billy, F., and Truchet, G. 1993. Abortion of infection during the Rhizobium meliloti-alfalfa symbiotic interaction is accompanied by a hypersensitive reaction. Plant J. 4:555-566.

Wang, J., Tóth, K., Tanaka, K., Nguyen, C. T., Yan, Z., Brechenmacher, L., Dahmen, J., Chen, M., Thelen, J. J., Qiu, L., and Stacey, G. 2014. A soybean acyl carrier protein, GmACP, is important for root nodule symbiosis. Mol. Plant-Microbe Interact. 27:415-423.

Wasternack, C., and Strnad, M. 2016. Jasmonate signaling in plant stress responses and development - active and inactive compounds. N. Biotechnol. 33 (5 Pt B):604-613.

Yaeno, T., Matsuda, O., and Iba, K. 2004. Role of chloroplast trienoic fatty acids in plant disease defense responses. Plant J. 40:931-941.

Zhang, P., Burton, J. W., Upchurch, R. G., Whittle, E., Shanklin, J., and Dewey, R. E. 2008. Mutations in a $\Delta^{9}$-stearoyl-ACP-desaturase gene are associated with enhanced stearic acid levels in soybean seeds. Crop Sci. 48:2305-2313 